\title{
Residential Demand for Broadband Telecommunications and Consumer Access to Unaffiliated Internet Content Providers
}

\author{
Jerry A. Hausman ${ }^{\dagger}$, J. Gregory Sidak ${ }^{\dagger \dagger}$, and Hal J. Singer ${ }^{\dagger \dagger}$
}

In this article, we examine the open access debate in the context of cable services and broadband Internet services from an antitrust framework. Our analysis is prompted by the recent AT\&T-MediaOne and AOL-Time Warner mergers, which raise issues concerning the impact of integrated cable content and Internet access to residential telecommunications. Economic analysis, demographic surveys and federal antitrust guidelines each indicate that the broadband Internet access market is distinct from the narrowband Internet access market. Emerging or competing technologies, such as satellite Internet services or digital subscriber lines, cannot discipline the broadband Internet access market over the relevant time horizons. Vertical integration increases the incentives and power of cable providers to discriminate against unaffiliated broadband content, thereby substantially decreasing consumer welfare. We conclude that the recent mergers of cable content and Internet access is the most current manifestation of the classic strategy of cable providers to control alternate channels of content distribution.

Introduction

I. Improperly Combining the Narrowband and Broadband Internet

Access Markets

A. Qualitative Evidence that the Broadband Internet Access Market is Distinct from the Narrowband Market.

B. Incorrectly Focusing on the Existence of a Narrowband Access Market

C. Both Theoretical and Empirical Analysis Support the Existence of a Distinct Broadband Internet Access Market

1. AT\&T's Own ISP Decision Model Supports the Conclusion that a Separate Broadband Market Exists

2. Estimation of the Cross-Price Elasticities between

$\dagger \quad$ MacDonald Professor of Economics, Massachusetts Institute of Technology.

$+\dagger$ F.K. Weyerhaeuser Fellow in Law and Economics, American Enterprise Institute for Public Policy Research.

$++\dagger$ Senior Vice President, Criterion Economics, L.L.C., Washington, D.C. This Article draws upon research that one or more of the authors conducted in various regulatory proceedings on behalf of America Online, Inc., Bell Atlantic Corporation, GTE Corporation, and SBC Corporation. 
Broadband Access and Narrowband Access Reveals that Broadband Prices Are Not Constrained by Narrowband Prices.

3. The Qualitative Results of the Market Definition Tests Will Not Change Over the Relevant Time Horizon 148

D. Neither Digital Subscriber Line nor Satellite Internet Services Can Discipline Price in the Broadband Internet Market over the Relevant Time Horizon

1. Digital Subscriber Lines Will Not Provide Price

Discipline Over the Relevant Time Horizon

2. Satellite Internet Services and Wireless Technologies

Will Not Discipline Price over the Relevant Time

Horizon.

E. The Broadband Internet Services Market Is Highly

Concentrated.

1. Standard Antitrust Analysis Demonstrates that the

Broadband Internet Services Market Is Highly

Concentrated

2. High Startup Costs Constrain the Fringe Participants'

Ability to Discipline Price in the Broadband Internet

Access Markets over the Relevant Time Horizon.

II. The Anticompetitive Effects of Expanding the Cable Footprint of a Vertically Integrated Cable Provider

A. A Larger Footprint Increases the Incentive and Opportunity to Discriminate against Unaffiliated Broadband Content

Providers

1. The Firm's Incentive to Discriminate Against

Unaffiliated Broadband Content and Conduit Providers

Increases with the Size of Its Footprint.

2. Cable Providers Have the Ability to Discriminate

Against Unaffiliated Content Providers in Several Ways. 160

3. The Decreased Variety in Content Will Cause

Substantial Consumer Welfare Losses

B. The Early Leader in Broadband Access Will Enjoy "Lock-in"

Effects.

III. Regulatory Review of Open Access and Market Definition 165

Conclusion 170 
Introduction

The open access debate has simultaneously arisen in several contexts. Most importantly, open access of cable modems that deliver broadband Internet services has been examined in light of the completed AT\&T-MediaOne merger and the proposed AOL-Time Warner merger. The issue also has arisen in the context of federal agency proceedings and congressional hearings on Internet policy. Finally, open access has been argued in the context of cable license transfers at the municipal level. To address the issue of open access in an antitrust framework, one must first address the question of market definition. If broadband services represent a distinct antitrust market, as we argue in this Article, then it is at least possible for a dominant provider of those services to exercise market power. Unless that conjecture is proven, however, all of the associated anticompetitive harms that have been articulated by rival broadband content and broadband conduit providers should be ignored.

In this Article, we consider the effects of broadband access on residential telecommunications. In particular, we concentrate on cable modems and digital subscriber line (DSL) offerings. We consider the competitive interaction for Internet usage of narrowband residential access and broadband access. We also consider the economic incentives and actions of the providers of narrowband and broadband access with respect to limiting the usage of broadband access. We further investigate the potential competitive effects for cable television, a sector of the economy where to date system operators have been able to exercise significant market power.

Much of the intellectual debate has resulted from the exchange between us and Professors Janusz A. Ordover of New York University and Robert D. Willig of Princeton University, whom AT\&T retained as expert witnesses in support of its acquisition of MediaOne, a larger cable television multiple system operator (MSO). ${ }^{1}$ We disagree with the analysis of Professors Ordover and Willig in two major respects. First, Professors Ordover and Willig improperly combine broadband Internet access and narrowband Internet access into one large Internet access market. Second, Professors Ordover and Willig erroneously dismiss the anticompetitive effects of the AT\&T-MediaOne merger. In particular, the merger will allow AT\&T to control the development of broadband content, software, and customer equipment, hindering the efforts of alternative broadband technologies to compete and subjecting consumers to higher e-commerce prices.

1 Declaration of Janusz A. Ordover and Robert D. Willig, on behalf of AT\&T Corp., Applications for Consent to the Transfer of Control of Licenses, MediaOne Group, Inc., Transferor, to AT\&T Corp., Transferee, CS Docket No. 99-251 (filed Sept. 17, 1999) (hereinafter MediaOne OrdoverWillig Declaration]. 
At the time of the merger, AT\&T was the nation's second-largest cable MSO. ${ }^{2}$ AT\&T also controlled Excite@Home Corp., the largest provider of residential broadband service with over 1.15 million subscribers in May 2000.3 Excite@Home had (and still has) exclusive contract rights to provide residential broadband service over the cable facilities of its three principal equity holders, AT\&T, Comcast Corporation, and Cox Communications, Inc., which collectively account for over 35 percent of the nation's cable subscribers.

At the time of the merger, MediaOne Group was the seventh largest cable MSO in the United States. ${ }^{4}$ Before the merger with AT\&T, MediaOne also jointly owned the second largest provider of residential broadband service in the United States, using the trade name "Road Runner." Road Runner provided residential broadband service over cable systems to more than 730,000 end-user subscribers. ${ }^{5}$ Road Runner had (and still has) exclusive contract rights through December 2001 to provide residential broadband service over the cable facilities of its two principal cable parents, MediaOne and Time Warner, which collectively accounted for more than 25 percent of the nation's cable subscribers.

On May 6, 1999, AT\&T and Media One agreed to merge in a transaction valued at roughly $\$ 56$ billion. As a result of this transaction, AT\&T would have substantial equity and management rights in both Excite@Home and Road Runner, which collectively served 60 percent of the nation's residential broadband users. According to the Department of Justice (DOJ), which subsequently compelled AT\&T-MediaOne to divest itself of its holdings in Road Runner, the merger would severely harm competition, by increasing AT\&T's "leverage in dealing with broadband content providers, enabling it to extract more favorable terms for such services," and enabling AT\&T to "make it less profitable for disfavored content providers to invest in the creation of attractive broadband content." Because it allowed the merging parties to retain control of Excite@Home and because it did not compel mandatory open access, the DOJ's decree did not address the more fundamental problem of potential anticompetitive outcomes arising from the vertical links in the broadband and cable industries.

2 This description borrows heavily from Competitive Impact Statement at 1, U.S. v. AT\&T Corp. \& Media One Group, Inc., No. 1:00CV01176 (D.D.C. filed May 25, 2000), available at http://www.usdoj.gov/atr/cases/f4800/4842.pdf [hereinafter Competitive Impact Statement].

$3 \quad I d$. at 4 . AT\&T currently holds approximately a 26 percent equity interest in Excite@Home and a majority of its voting stock. Id.

$4 \quad I d$. MediaOne also held a 25.51 percent equity interest in Time Warner Entertainment, which controls all of the cable systems and video programming of Time Warner Inc. Id.

$5 \quad$ Id. at 5 . MediaOne owned approximately 34 percent of Road Runner. Id.

6 Competitive Impact Statement, supra note 2, at 2. 
AT\&T's acquisition of MediaOne represents a traditional cable strategy of controlling alternative sources of delivery for video programming. Before AT\&T's recent cable acquisition initiative, the most recent implementation of this anticompetitive strategy was the attempt by a coalition of cable firms to control satellite delivery of video programming, the first alternative medium for multichannel video programming. ${ }^{7}$ In the Primestar case, the Department of Justice sued to block that combination and characterized direct broadcast satellite (DBS) as "the first real threat to the cable monopoly." The acquisition of MediaOne will allow AT\&T to control broadband Internet delivery of video programming, the second alternative medium for multichannel video programming. Even AT\&T's own economic experts admit that "Internet video streaming clearly competes, at a minimum, with video programming offered by cable systems, satellite companies, and television broadcasters." " By increasing AT\&T's market power over broadband programmers and advertisers, the merger will substantially harm consumers by limiting their choices of broadband content and raising the price of e-commerce.

In Part II of this Article, we demonstrate that Professors Ordover and Willig incorrectly combine the narrowband access and broadband access markets. By focusing on the question of whether narrowband access customers would switch to broadband access alternatives, Professors Ordover and Willig comment exclusively on the existence of a narrowband access market. That analysis, however, is uninformative. Instead, the relevant question is whether a sufficient number of broadband customers would switch to narrowband Internet service in the face of a non-transitory price increase. Professors Ordover and Willig highlight the narrowing price differential between narrowband and broadband Internet connections, which is also irrelevant for the purpose of establishing a separate broadband Internet access market. We show that AT\&T's own Internet service provider (ISP) decision model supports the conclusion that a separate market exists for broadband Internet access. Because the typical broadband user spends so

7 See Complaint at 3, United States v. Primestar, Inc., No. 1:98CV01193 (D.D.C. filed May 12, 1998), available at http://www.usdoj.gov/atr/cases/f1700/1757.htm.

8 Press Release, U.S. Department of Justice, Justice Department Sues to Block Primestar's Acquisition of News Corp./MCI's Direct Broadcast Satellite Assets 1 (May 12, 1998) (on file with Yale Joumal on Regulation), available at http:/Www.usdoj.gov/atr/public/press_releases/1998/1758.htm.

9 MediaOne Ordover-Willig Declaration, supra note 1, ๆ 117. For additional assessments of the coming competition between cable and streaming video over broadband, see Dissenting Statement of Commissioner Harold Furchtgott-Roth, Annual Assessment of the Status of Competition in Markets for the Delivery of Video Programming, CS Docket No. 98-102, 13 F.C.C.R. 24,284, at 24,491 (released Dec. 23,1998 ) (explaining why competition to cable should include "broadcast televisions stations, DBS, ... and, at some point in the not too distant future, intemet streaming video"); and BRUCE M. OWEN, THE INTERNET CHALLENGE TO TELEVISION 8 (1999) (describing the Internet as the "first potential substitute for broadcast television as an in-home entertainment delivery medium since the rental video-cassette"). 
much time on the Internet, a five percent price increase on broadband access would not overcome the value of leisure time lost for the vast majority of broadband customers who were considering a narrowband alternative; hence, a hypothetical monopoly provider of broadband Internet access could profitably sustain a five percent price increase for a non-transitory period. Finally, estimation of the cross-price elasticities between broadband access and narrowband access reveals that broadband access prices are not constrained by narrowband access prices, a finding that confirms that broadband access is not in the same market as narrowband access.

In Part III, we highlight the anticompetitive effects of a merger that expands the cable footprint of a vertically integrated cable provider. In particular, defenders of a hands-off approach to open access disregard network effects in broadband Internet services that could allow an entrenched first-mover to gain durable monopoly power. The improper combination of two separate Internet access markets allows one to dismiss any concerns that AT\&T and MediaOne will use their combined share of broadband Internet customers to exercise market power in the supply of broadband content and broadband advertising. Contrary to the claims of hands-off advocates, we demonstrate that a vertically integrated broadband provider such as AT\&T will have a strong incentive and opportunity to discriminate against unaffiliated broadband content providers. AT\&T's incentive to discriminate derives from the fact that AT\&T's gains from higher margins on broadband content (supplied to customers whom AT\&T will retain) will likely outweigh its losses, if any, in Internet access charges (from customers who defect to another supplier of Internet access). Because some of AT\&T's broadband customers who remain after AT\&T limits choices would have preferred similar content from non-affilated providers, there will be substantial losses in consumer welfare.

In Part IV, we provide a summary of the regulatory review of open access and issues of market definition. First, we explain the DOJ's remedy in the AT\&T-MediaOne merger. Next, we explain why the Federal Communications Commission (FCC) decided not to add any conditions to that merger beyond what was already prescribed by the DOJ. Finally, we explain the Federal Trade Commission's (FTC) requirement of open access in the proposed merger of AOL and Time Warner. 


\section{Residential Demand for Broadband}

\section{Improperly Combining the Narrowband and Broadband Internet Access Markets}

One of the important product markets affected by the AT\&T-MediaOne merger is broadband Internet access for residential users. ${ }^{10}$ The merger also affects vertically related markets, such as the portals and streaming video markets. From a consumer's perspective, the relevant geographic market is local because one can purchase broadband Internet access only from a local residence. Stated another way, a hypothetical monopoly supplier of broadband Internet access in a given geographic market could exercise market power without controlling the provision of broadband access in neighboring geographic markets.

The FCC's own examination of the broadband Internet industry in 1999 suggested that the broadband Internet access market should be treated as a separate product market from narrowband Internet access. In particular, the FCC designated $200 \mathrm{kbps}$ (upstream and downstream) as the point at which "broadband" services begin, because that speed "is enough to provide the most popular forms of broadband - to change web pages as fast as one can flip through the pages of a book and to transmit full-motion video."11 Moreover, the FCC's Office of Plans and Policies noted in 1997 that analog modem bandwidth "is largely insufficient to support real-time video transmissions over the Internet." ${ }^{\prime 2}$ In an October 1999 report on the state of broadband competition, the FCC's Cable Bureau suggested that broadband Internet services represent a distinct antitrust market. ${ }^{13}$ To couch the issue in terms of the language of antitrust, narrowband connections are therefore evidently viewed by the FCC as technically incapable of supporting services that are considered substitutes for broadband applications.

In this Part, we show that the FCC's assessment comports with the conclusion that follows from application of the DOJ's and FTC's 1992 Horizontal Merger Guidelines (the Merger Guidelines), which provide a specific algorithm for defining the relevant product market affected by a

10 Throughout the rest of this Article, we use the phrase "broadband Internet access" to mean broadband Internet access for residential users.

11 Inquiry Concerning the Deployment of Advanced Telecommunications Capability to All Americans in a Reasonable and Timely Fashion, and Possible Steps to Accelerate Such Deployment Pursuant to Section 706 of the Telecommunications Act of 1996, Report, CC Docket No. 98-146, 14 F.C.C.R. 2398, at 2406 (released Feb. 2, 1999).

12 KeVin Werbach, Digital ToRnado: The InTERnet and Telecommunications Policy 41 (Fed. Communications Comm'n, OPP Working Paper No. 29, 1997), available at http://www.fcc.gov/opp/workingp.html.

13 See Deborah A. LATHEN, Federal COMMUNications COMmission, Broadband Today: A Staff Report to William E. Kennard, Chairman, Federal Communications COMMISSION 47 (1999) (describing a "nascent residential broadband market") [hereinafter BROADBAND TODAY]. 
proposed merger or acquisition. ${ }^{14}$ Following the Merger Guidelines, one begins with a narrow definition of the relevant product market and asks the following question: Could a hypothetical monopoly supplier of the product in question profitably sustain a five percent price increase for a substantial time period, which is usually assumed to be two years?

If the answer is no- that is, the supplier would need control over related product markets to make the price increase profitable-then the product market must be expanded to cover those neighboring products, and the exercise is repeated. If the answer is yes-that is, the increased profit on inframarginal customers outweighs the lost variable profits on marginal customers who switch suppliers when faced with a price increase-then the narrowly defined product represents its own relevant antitrust market. Assuming that we begin with broadband Internet access services, this "critical share" analysis can be performed to determine the number of customers who could switch to narrowband access alternatives before the price increase of the hypothetical monopolist would be rendered unprofitable. ${ }^{15}$

\section{A. Qualitative Evidence that the Broadband Internet Access Market is Distinct from the Narrowband Market}

There are several qualitative reasons to suppose that the broadband Internet access market is distinct from the narrowband market.

First, the demographic profiles of the typical broadband and narrowband users indicate two distinct user groups. In July 1999, the Strategis Group surveyed current narrowband Internet users as to their willingness to purchase broadband Internet access. ${ }^{16}$ The results of that survey paint strikingly different portraits of who may become the typical broadband user and the typical narrowband user. Narrowband Internet users interested in broadband are more likely to be male, younger, less wealthy, and spend more time on-line than those who are not. Table 1 compares the demographic characteristics of narrowband users interested in broadband connections at $\$ 40$ per month with the demographic characteristics of those who are not.

\footnotetext{
(1992).

14 U.S. DEP'T OF JuSTICE AND FED. TRADE COMM'N, HORIZONTAL MERGER GUIDELINES $\S 1.1$

15 For a more extensive discussion of critical share, see Jerry A. Hausman, Gregory K. Leonard \& Christopher A. Vellturo, Market Definition Under Price Discrimination, 64 ANTITRUST L.J. 367 (1996).

16 Strategis Group, High-SPEEd INTERNET 1998-1999 (1998) [hereinafter STRATEGIS GROUP]. 
Residential Demand for Broadband

Table 1: Comparison of Demographic Profiles of AVerage NARROWBAND USERS INTERESTED AND NOT INTERESTED IN BROADBAND CONNECTIONS AT \$40 PER MONTH

\begin{tabular}{ccc}
\hline $\begin{array}{c}\text { Demographic } \\
\text { Characteristic }\end{array}$ & $\begin{array}{c}\text { Average of } \\
\text { Narrowband Users } \\
\text { Not Interested in } \\
\text { Broadband at } \$ 40\end{array}$ & $\begin{array}{c}\text { Average of } \\
\text { Narrowband } \\
\text { Users Interested } \\
\text { in Broadband at } \\
\$ 40\end{array}$ \\
\hline $\begin{array}{c}\text { Gender (percent male) } \\
\text { Age (years) }\end{array}$ & 33.3 & 66.7 \\
$\begin{array}{c}\text { Annual Household Income } \\
\text { (thousands \$) }\end{array}$ & 51.1 & 33.2 \\
$\begin{array}{c}\text { Total Weekly Hours of } \\
\text { Internet Use (hours) }\end{array}$ & 61.5 & 53.7 \\
$\begin{array}{c}\text { Length of Internet Usage } \\
\text { (years) }\end{array}$ & 6.2 & 9.5 \\
\hline
\end{tabular}

Note: Weighted averages computed by assuming median value of the range for each grouping.

As Table 1 shows, there is a sharp distinction between a consumer who fits the broadband profile and one who fits the narrowband profile. According to the Strategis Group, of all the factors included in its survey, total usage is the most influential determinant of demand for residential broadband Internet access. ${ }^{17}$

Second, many of the services supported by broadband connections are not available through narrowband connections. The demand for applications that can be supported only by high-bandwidth connections also suggests that the product markets for narrowband and broadband are distinct. Functionalities that are only supported by broadband connections include real time video programming, ${ }^{18}$ on-demand video, ${ }^{19}$ customized music and video libraries, ${ }^{20}$ real-time radio programming, ${ }^{21}$ interactive multi-player gaming, ${ }^{22}$ high-speed telecommuting, ${ }^{23}$ and interactive advertising and e-

\footnotetext{
17 Id. at 31.

$18 \mathrm{Jim}$ Hu, Music Festival in Tune With Net Space. CNET NEwS, July 22, 1999, at http://news.cnet.com/news/0-1005-200-345241.html.

19 Carol Wilson, Broadband: Get Ready for the Gale, ZDNET NEWS, June 26, 1999, at http://www.zdnet.com/zdnn/stories/news/0,4586,2281301,00.html.

20 Gary Arlen, Swing and Sway with Big Bandwidth, MUltichanNel NEWs ONLINE, Mar. 29, 1999, at http://www.multichannel.com/weekly/1999/13/arien 13.htm.

21 Randall Rothenberg, Rob Glaser, Moving Target, WIRED, Aug. 1999, at 131.

22 William O'Neal, Frag the Lag! Broadband Access: The Gamer's Edge, CNET GAMECENTER, Apr. 14, 1999, at http://www.gamecenter.com/Features/Exclusives/Broadband/.

23 Wilson, supra note 19.
} 
commerce. $^{24}$ In a recent ZDNet survey, the demand for broadband connections was explained in particular by a desire to download music, video, and games. ${ }^{25}$ Respondents who showed an interest in broadband connections were asked which on-line activities they would consume in larger quantities as a result of faster connections. The results indicate that 63 percent of respondents were motivated by a desire to download more audio, video, or game files, while 54 percent were motivated by a desire to enjoy streaming audio or video. ${ }^{26}$

In contrast, the demand for narrowband connection is driven by a completely different set of applications, including email, research, headline news, entertainment, shopping, chat, general surfing, financial news, sporting news, travel services, and banking. ${ }^{27}$ Although some information-intensive applications are supported through narrowband connections, the quality of use is often significantly sacrificed. For example, to the extent that immediacy is important for some users, any delay in interactive applications would diminish the Internet experience. This observation suggests that the consumer's decision to choose broadband over narrowband will depend on more than the price differential and download speeds alone. For example, interactive applications and live events are vastly superior when experienced with broadband connections. In the following section, we examine in detail the manner by which consumers make this decision of whether to go with narrowband or broadband.

Third, the prices for broadband and narrowband Internet access are substantially different. In the Washington, D.C. area in late 1999, for example, the price of broadband Internet access via cable modems is at least twice as high as narrowband access. For example, Erols, a local ISP, charges its customers \$11 per month for narrowband access while Comcast@Home charges existing cable customers $\$ 39.95{ }^{28}$ This price differential suggests, qualitatively, that the two products may be in distinctly different antitrust markets. In the following section, we are able to confirm empirically that broadband Internet access represents a separate product market from narrowband access.

24 Fred Dawson, Excile@Home Gets Rolling On Broadband-Enhanced Ads, MULTICHANNEL NEws ONLINE, June 14, 1999, at http://www.multichannel.com/weekly/ 1999/25/exc25.htm.

25 ZDNet Study Suggests Broadband Adoption Will Be Driven by Increasing Demand for Access to Music, Video, and Games, PR NEwSwIRE, June 29, 1999. ZDNet InternetTrak is a quarterly survey-based study on Internet and computing trends.

26 Id.

27 STRATEGIS GROUP, supra note 16, at 2.

28 The price of Comcast@Home's cable Internet service was downloaded from the company web site on August 1, 1999. See Comcast Online, $a t$ http://www.comcastonline.com/ faq.asp (last visited Dec. 16, 2000). Because Internet service and transport are included in the broadband monthly charge, a more appropriate comparison may be the price of a narrowband ISP plus the price of a second telephone line versus the price of a broadband connection. 


\section{B. Incorrectly Focusing on the Existence of a Narrowband Access Market}

To be sure, mere differences in demographic characteristics of customers interested in broadband and narrowband Internet access do not constitute a proof of two separate antitrust markets. To determine whether broadband Internet services represent a separate antitrust product market, one must focus on the proportion of the marginal broadband customers-that is, those broadband customers who would depart in the face of a small price increase-relative to the size of all broadband customers. ${ }^{29}$ That ratio, known as the "critical share" of broadband customers, represents the fraction of broadband customers who could depart yet still leave a hypothetical monopoly supplier of broadband services as well off after a price increase. Similarly, although completely irrelevant for the purpose of this matter, to determine whether narrowband represents a separate market, one must focus on the proportion of the marginal narrowband customers-that is, those narrowband customers who would depart in the face of a small price increase-relative to the size of all narrowband customers.

In September 1999, Professors Ordover and Willig submitted a declaration to the FCC in support of AT\&T's proposed merger with MediaOne. Professors Ordover and Willig argued that the merger of AT\&T and MediaOne would not provide the merged entity with the incentive or ability to exercise market power over its broadband customers. The authors correctly observed that mere differences in demographic characteristics of customers interested in broadband and narrowband Internet access do not constitute a proof of two separate antitrust markets. ${ }^{30}$ In addition, they emphasized that, after incorporating the price of a second telephone line, the prices of broadband access and narrowband access are somewhat similar; hence, they concluded that narrowband and broadband Internet connections must be in the same product market. ${ }^{31}$ From those facts, they suggested that the existence of close substitutes like dial-up Internet connections and digital subscriber lines would undermine AT\&T's ability to implement any anticompetitive strategies. For example, if AT\&T raises end user prices or discriminates against nonaffiliated content providers, the authors argued, customers would substitute away from its offerings sufficiently to cause such a strategy to be unprofitable. Finally, they argued that any difference between broadband and narrowband applications would be negligible: "[T]he overwhelming majority of Internet content is accessible by both narrowband

29 All broadband customers are defined as the sum of the marginal and "inframarginal" customers, where inframarginal is defined as those customers who would not depart in the face of a small price increase.

30 MediaOne Ordover-Willig Declaration, supra note $1, \uparrow 91$

31 Id. $\$ 92$ (emphasis in original). 
and broadband last-mile transport; the only difference is the speed or quality at which the content downloads." 32

The existence of one antitrust market does not always imply the existence of another. Stated another way, the relevant cross-price elasticities are not typically identical. ${ }^{33}$ Professors Ordover and Willig blur that distinction by speaking of the "great deal of demand cross-elasticity and opportunities for substitution between the two modes of Internet access." 34 By focusing on the decision to "switch from their current narrowband providers," Professors Ordover and Willig only call into question the existence of a separate narrowband market. $^{35}$ Unfortunately, the determination of whether a hypothetical monopoly provider of narrowband transport can exercise market power in the market for narrowband transport does not imply anything about the existence of a broadband transport market. Hence, the attempted economic analysis of Professors Ordover and Willig crumbles. In essence, Professors Ordover and Willig are playing on the oneway substitutability from narrowband to broadband Internet services. While all narrowband applications are supported by broadband Internet connections, the same is not true in reverse-growing numbers of broadband applications cannot be supported over narrowband Internet connections.

\section{Both Theoretical and Empirical Analysis Support the Existence of a Distinct Broadband Internet Access Market}

Professors Ordover and Willig emphasize that, after incorporating the price of a second telephone line, the prices of broadband access and narrowband access are similar; hence, they reason, narrowband and broadband Internet connections must be in the same product market. ${ }^{36}$ The assertion that the broadband and narrowband Internet access prices are similar is wrong for at least three reasons.

First, although the price of connection (when incorporating the price of a second line) to the Internet may be similar, the quality-adjusted price is not. In particular, a second line is not always "on," is subject to congestion, ${ }^{37}$ and cannot simultaneously support several broadband applications such as

32 MediaOne Ordover-Willig Declaration, supra note 1, | 92 (emphasis in original).

33 The Slutsky equation of economic analysis states that the compensated cross-price derivatives are equal. See, e.g., HAL R. VARIAN, MiCrOeCONOMIC ANALYSIS 119 (3d ed. 1992). However, since the cross-price elasticities depend on quantities purchased, the cross-price elasticities typically differ, often by large amounts if one product has significantly higher sales than the other, as would occur in the current situation.

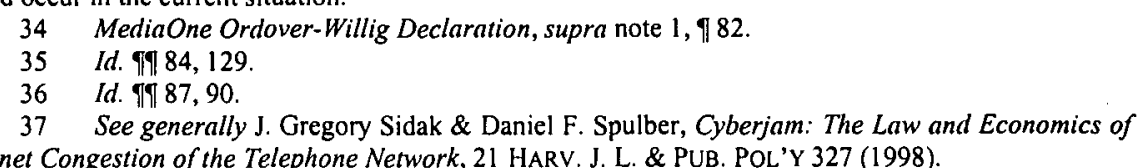
140 
streaming video and video conferencing. Second, many heavy Internet users who own a wireless telephone can avoid the cost of a second line. ${ }^{38}$ If the choice to subscribe to wireless was made before the Internet access decision, as would seem likely to be the case for many Internet users, we believe that the monthly price of the wireless connection should not be included in the price of narrowband access. Third, if the price of a second telephone line should be included in the price comparison, then certainly the installation cost of a broadband connection (typically $\$ 150$ for a cable modem) should be incorporated as well. Under any reasonable comparison, the prices of broadband and narrowband Internet access are different and hence support, but in no way confirm, the notion of distinct antitrust markets. ${ }^{39}$

Even if the assertion of equivalence between broadband and narrowband Internet access prices were true, the proof that a separate broadband market exists would not be affected. First, for the same reason that evidence of diverging prices is not definitive, evidence of similar prices between two products-say, a can of Coke and an arcade game-does not imply that the two products are in the same product market. Second, the data demonstrate that prices of second telephone lines vary greatly across different regulatory jurisdictions, that the price of broadband Internet access remains relatively constant. ${ }^{40}$ These data demonstrate that narrowband Internet access does not constrain the price of broadband Internet access. As we demonstrate in the following two subsections, a narrowing price differential between broadband and narrowband Internet access actually facilitates a five percent price increase by a hypothetical monopoly provider of broadband Internet access, as the narrowband alternative becomes less attractive. Stated another way, a narrowing price differential between broadband and narrowband access, as Professors Ordover and Willig claim, supports the notion of a distinct broadband Internet access market.

38 In particular, college students and singles with roommates reportedly use home telephone lines for their computer modems only, and make voice calls on digital pocket telephones. See, e.g., Mike Mills, Dollars and Dazzle in '99; Telecommunications Developments May Ease Pain of New Rate Increases, WASH. POST, Jan. 4, 1999, at F18.

39 In comparing the costs of narrowband and broadband Internet connections, the FCC incorrectly incorporates the costs of a computer modem, which is included in almost every computer purchase order. Hence, on the margin, the typical customer does not incur that expense when choosing a narrowband Intemet connection. See Inquiry Concerning the Deployment of Advanced Telecommunications Capability to All Americans in a Reasonable and Timely Fashion, and Possible Steps to Accelerate Such Deployment Pursuant to Section 706 of the Telecommunications Act of 1996, Report, supra note 11 , at 2444.

40 The price data were obtained through telephone calls to the companies that offered the specified services in each of the respective areas. The calls took place August 10-15, 1999. 
1. AT\&T's Own ISP Decision Model Supports the Conclusion that a Separate Broadband Market Exists

We begin with the basic premise that, when choosing the form of Internet access, a consumer must weigh the greater out-of-pocket costs associated with broadband Internet access against the wasted leisure time (due to slower speeds) and diminished quality of experience (due to fewer applications) associated with a narrowband connection. Because Professors Ordover and Willig believe the quality of the experience to be nearly identical across both mediums, AT\&T's decision model implies that consumers will choose broadband over narrowband if and only if the increase in the value of leisure time saved outweighs the increase in monthly out-of-pocket expenditures. In particular, they argue that any difference between broadband and narrowband applications will be negligible: "In any event, the overwhelming majority of Internet content is accessible by both narrowband and broadband last-mile transport; the only difference is the speed or quality at which the content downloads. ${ }^{, 41}$ That assertion raises the following question: Could a hypothetical monopoly supplier of broadband Internet access in a geographic market sustain a five percent price increase conditional on the assumption that consumers only consider differences in speed when choosing their ISP?

If one can show that a five percent price increase is profitable under the assumption that the quality of the broadband and narrowband experiences is the same, then the price increase would be even more profitable when that counterfactual assumption is relaxed. To conduct that analysis, one must first calculate the out-of-pocket costs associated with the choice of broadband and narrowband Internet connections. We do this by using the monthly Internet service fees of Erols (plus the costs of a second telephone line and installation fee amortized over one year) and @Home (plus the cost of a cable modem and installation fee amortized over one year) to compute an out-of-pocket price differential associated with choosing broadband transport over narrowband transport. That differential is equal to $\$ 8.38$ per month. ${ }^{42}$

41 MediaOne Ordover-Willig Declaration, supra note 1, ๆ92 (emphasis in original). Although that assertion may be true for the inframarginal narrowband customer, it completely ignores the relevant market-definition question: whether the majority of broadband content-not all Internet content-is accessible by both narrowband and broadband last-mile transport.

42 The monthly service fee of Erols and @Home are $\$ 11$ and $\$ 40$, respectively. The cost of a second telephone line in the Maryland suburbs of Washington, D.C. is $\$ 23.03$ per month. The installation costs of a second telephone line are $\$ 95$ (for re-wiring the telephone jack) plus a $\$ 26$ connection charge. Interview with Bell Atlantic representative. The installation cost for @Home is \$149. See Comcast Online, supra note 28 . When the installation costs are amortized over three years, the monthly price differential falls to $\$ 6.78$. 
The value of the leisure time saved is equal to the product of the hours of leisure time saved due to faster download speeds and the value of one's leisure time per hour. A significant difficulty in estimating the amount of leisure time saved is that, for at least some fraction of the time spent downloading content with a narrowband connection, the consumer can engage in other leisure activities, such as reading or watching television. We assume that the best proxy for the value of one's leisure time is one's wage rate. Using figures from the Strategis Group, the average hourly wage rate of subscribers interested in broadband connections was, as of December 1998, $\$ 29 .^{43}$

AT\&T's ISP decision rule can be simplified to the following expression: A consumer will choose broadband over narrowband Internet access if and only if

$$
t w>p_{b}-p_{n}
$$

where $t$ is amount of leisure time saved, $w$ is the wage rate, $p_{b}$ is the monthly price of broadband and $p_{n}$ is the monthly price of narrowband Internet access. Dividing both sides by the wage rate gives

$$
t>\left[p_{b}-p_{n}\right] / w
$$

Given the out-of-pocket price differential of $\$ 8.38$ per month and the value of leisure time equal to $\$ 29$ per hour, a consumer would only choose broadband transport over narrowband transport (under AT\&T's decision model) if the amount of leisure time that she saved exceeds 17 minutes per month (that is, $[\$ 52.50$ per month $-\$ 44.11$ per month] $/ \$ 29$ per hour $=0.29$ hours $=17.3$ minutes).

Next we compute the consumer's decision rule under the assumption that prices of broadband connections were to rise by five percent. Under the new parameters, a consumer chooses broadband Internet access over narrowband Internet access so long as the value of that consumer's leisure time saved exceeds 23 minutes per month (that is, $[\$ 52.50$ per month $\times 1.05$ $\$ 44.11$ per month] $/ \$ 29$ per hour $=0.38$ hours $=22.8$ minutes).

Finally, one must estimate the share of broadband customers that would switch to narrowband Internet access given the five percent price increase. Assuming that the marginal cost of providing broadband Internet access is zero, the critical share of customers who must switch to narrowband to render a five percent price increase unprofitable is 4.8 percent. ${ }^{44}$ Based on

43 STRATEgis GROUP, supra note 16 , at 31 .

44 The five percent price increase will be profitable only if the gains from the inframarginal customers (that is, those who remain with broadband transport after the price increase) outweigh the lost 
the exercise above, the marginal customers download content in such a way that their amount of leisure time saved as a result of faster speeds is between 17 and 23 minutes per month.

Relying on the Strategis Group's distribution of Internet users, we believe that such customers represent a significantly smaller share of the broadband Internet access market than 4.8 percent. ${ }^{45}$ Indeed, the average amount of time spent on the Internet by those customers interested in broadband connections was 2,442 minutes per month. Stated another way, we believe that the amount of leisure time that would be saved by customers who spend 2,442 minutes per month on the Internet must substantially exceed 23 minutes per month. Consequently, a five percent price increase would be profitable for a hypothetical monopolist to impose on these consumers and thus, according the Merger Guidelines' market-definition test, broadband Internet access represents a separate antitrust market. Because the five percent price increase would be profitable under the extreme case in which the quality of the experiences for broadband and narrowband usage was identical and switching costs were zero, ${ }^{46}$ the same five percent price increase under more realistic assumptions would be even more profitable. Hence, according to the test prescribed by the Merger Guidelines, broadband Internet access represents a separate antitrust product market from narrowband Internet access.

\section{Estimation of the Cross-Price Elasticities between Broadband Access and Narrowband Access Reveals that Broadband Prices Are Not Constrained by Narrowband Prices}

The question of market definition can also be tested empirically. If it can be shown that narrowband Internet access prices (including the access charge plus the price of a second telephone line) do not constrain broadband Internet access prices, then a hypothetical monopoly provider of broadband Internet access could more easily sustain a five percent price increase; hence, the existence of a separate broadband Internet access market is more plausible. Professors Ordover and Willig criticized one of the present

revenues from the customers who switch to narrowband connections. Assuming zero marginal cost, the gains from inframarginal customers is equal to $.05 \mathrm{x}$ price $\mathrm{x}$ number of inframarginal customers, while the lost revenues from marginal customers is $1 \times$ price $x$ number of marginal customers. The decision rule simplifies to $q /(1-q)=.05$, where $q$ is the inframarginal customers. Solving for $q$ gives $q=4.8$. It is important to note that this estimate is conservative because if there were positive marginal costs, the lost variable profits from those customers who switch to narrowband transport would be lower, which would raise the critical share.

45 Strategis Group, supra note 16 , at 31.

46 Some obvious switching costs that would constrain the ability of a broadband customer to switch to narrowband are (1) long-term contracts, (2) the costs of changing one's email address, and (3) the cost of establishing a second telephone line. 
authors' previous econometric work on market definition for Internet access for being "poorly specified, inadequately described, and inappropriate to actual market conditions." ${ }^{, 47}$ In this section, we address each of those criticisms in turn. $^{48}$

In response to the criticism of inadequate description, we present a detailed account of the benchmark regression results. To conduct the econometric analysis, we gathered price data in August 1999 from 41 states and 59 MSOs where Excite@Home and Road Runner were then currently being sold. For cable subscribers the broadband access price varied from $\$ 34.95$ per month to $\$ 64.95$ month. ${ }^{49}$ We also considered the installation fee, which varied from $\$ 50$ to $\$ 150$. We amortized this installation fee over different periods in various regression specifications, depending on the predicted churn rate for broadband customers. For narrowband Internet access, we collected data from the incumbent local exchange carriers (ILECs) providing service in the areas served by the local cable provider. ${ }^{50}$ Prices for second telephone lines (used, for instance, by many AOL customers) varied from $\$ 7.70$ to $\$ 47.62$ per month. ${ }^{51}$ Installation costs for a second telephone line varied from $\$ 16.90$ to $\$ 55.30 .^{52}$ Again we amortized the installation cost for the second telephone line. Given that the "standard" price for the@Home cable service is $\$ 40$ per month and the price for second lines for narrowband access varies widely from $\$ 8$ to $\$ 48$ per month, plus the standard fee which is nationwide for narrowband ISPs (for example, $\$ 21.95$ per month for AOL), the data demonstrate conclusively that the Merger Guideline test for market definition places narrowband Internet access in a separate market from broadband Internet access. The straightforward observation is that narrowband access prices differ by a factor of over 300

47 MediaOne Ordover-Willig Declaration, supra note 1, 194 (criticizing Declaration of Jerry A. Hausman, on behalf of America Online, Inc., Joint Applications of AT\&T Corp. and TeleCommunications, Inc. for Control to AT\&T of Licenses and Authorizations Held by TCI and Its Affiliates or Subsidiaries, Federal Communications Commission, CS Docket No. 98-178 (filed Oct. 29, 1998)).

48 Professors Ordover and Willig emphasize that one of us failed to respond to their econometric critique (presented in the AT\&T-TCI proceeding) in the first round of the proceeding involving AT\&T's proposed acquisition of MediaOne: "Tellingly, while Dr. Hausman has provided a Declaration in this proceeding, he does not respond to any of these criticisms." Id. \ 95.

49 Prices for non-cable subscribers are typically $\$ 10$ per month higher. Consideration of these prices for customers who do not subscribe to cable had no significant effect on the results.

50 These data cover the price of monthly telephone access, not the price to the ISP. Although @Home and Road Runner provide both services in their price, because many narrowband ISPs provide national service at a single price, the price of ISP service will be included in the intercept coefficient in the regression specification.

51 For residential customers who do not use a second (or higher) telephone line, the marginal price of access is zero, everywhere but in New York City, so long as a local network node (PAD) exists. We used different weighted averages for use of first and second telephone lines in some of the regression specifications, but the results were not sensitive to the particular weights used.

52 That installation cost only captures the connection fee and does not reflect the costs of rewiring the telephone jack. 
percent, while broadband access prices do not vary in any way with these differences. Thus, variations in the price of narrowband access cannot explain the variations in the price of broadband access. Otherwise, when the price of a second telephone line changes from $\$ 48$ to $\$ 8$ per month, we would expect to observe a decrease in the price for the broadband access service. No significant decrease is found, which demonstrates the existence of separate product markets for antitrust purposes. ${ }^{53}$

Table 2 shows the benchmark results of a regression employing the price of broadband access (either @Home or Road Runner) as the left-hand side variable. The price variable is specified in logarithms. The right-hand side variables are an intercept, an indicator variable for Road Runner, and a variable for second telephone line prices from the ILEC, either in levels or in logs. ${ }^{54}$

TABLE 2: BenCHMARK REgRession OF BROAdBAND ACCESS PRICES ON NARROWBAND ACCESS PRICES

\begin{tabular}{lccc}
\hline Variable & $\begin{array}{c}\text { Est. } \\
\text { Coefficient }\end{array}$ & $\begin{array}{c}\text { Est. Std. } \\
\text { Error }\end{array}$ & $\begin{array}{c}\text { Est. t- } \\
\text { statistic }\end{array}$ \\
\hline Log Price of Broadband & & & \\
Access ${ }^{(1)}$ & & & \\
\hline Intercept & 4.03 & .090 & 47.7 \\
Log Price of Narrowband & -0.003 & .026 & -0.102 \\
Access ${ }^{(2)}$ & & & \\
Road Runner Indicator & -0.116 & .013 & -8.64 \\
\hline Number of observations & 59 & & \\
Standard error of regression & .011 & & \\
$\mathrm{R}^{2}$ & .572 & & \\
\hline
\end{tabular}

Note: (1) Broadband access price is the log of cable broadband access price plus amortized monthly cost of installation. (2) Narrowband access price is the $\log$ of the price of a second telephone line plus second-line fees plus amortization of the installation cost.

The estimated coefficient for the price of estimated narrowband access is essentially zero ( -.003 , which is extremely small (less than 1 percent) and nowhere near statistical significance). The estimated $t$-statistic is 0.10 , well

53 Some narrowband Internet customers do not use a second telephone line. We have also analyzed the data using a weighted average of customers who use a first or second telephone line. The results do not differ significantly, as discussed in the previous footnote.

54 The ILEC's price of second telephone line service is treated as predetermined in the regression specification because it is set by regulation, not by market forces. Also, a Hausman specification test did not reject exogeneity. See Jerry A. Hausman, Specification Tests in Econometrics, 46 ECONOMETRICA 1251 (1978). Furthermore, regulation requires ILEC tariffs for residential lines to be identical across a given service area. 
below conventional levels of statistical significance. Thus, the hypothesis that the price of narrowband access does not affect the price of broadband access (transport) and ISP service is not rejected. Our finding is that lower narrowband access prices do not constrain the prices charged for broadband access. Because the price of AOL is not included in any explanatory variable, its effect is contained in the estimate of the intercept coefficient.

The findings are quite uniform across different specifications corresponding to different definitions and amortization periods for installation costs. The estimated coefficient of the narrowband access price variable is found to be very small and statistically insignificant. The Road Runner indicator variable, however, is about -11.6 percent and highly statistically significant with a $t$-statistic of 8.6. Thus, Road Runner is priced significantly below @Home, on average. We find similar results if we limit the sample to Excite@Home MSOs, with the regression coefficient for narrowband access now estimated to be 0.0126 , again extremely small with a very low $t$-statistic of $0.3857 .^{55}$

Professors Ordover and Willig also argue that the coefficients in the benchmark regression might be biased due to an omitted variables problem. In particular, they suggest including the average income of the community as well as some measure of the cost of the calls from the residence to the ISP. ${ }^{56}$ We address these criticisms by including in the regression the median household income and the average population density for the relevant markets. We also include age variables for the population. The demographic control variables were not statistically significant, and the main coefficient of interest-the effect of narrowband access price-did not change in any meaningful way. ${ }^{57}$ Indeed, we do not reject the hypothesis that the coefficient of the estimated log price of narrowband access is the same, whether or not demographic variables are included. ${ }^{58}$ The results of three additional regressions with different specifications are presented in the Appendix. Thus, we continue to conclude that the price of narrowband access does not constrain the price of broadband access. Broadband Internet access is a separate relevant market for antitrust purposes.

55 To help interpret the coefficient estimate, even if it were statistically different from zero (which it is not by a long shot), note that a 10 percent decrease in the price of narrowband Internet access price would be associated with an expected decrease of 0.12 percent in the Excite@Home priceessentially zero (about 5 cents per month).

56 Declaration of Janusz A. Ordover and Robert D. Willig, on behalf of AT\&T Corp., Joint Application of AT\&T Corp. and Tele-Communications, Inc. for Transfer of Control to AT\&T of Licenses and Authorizations Held by TCl and its Affiliates Or Subsidiaries, CS Docket No. 98-178, ๆ 16 (filed Nov. 13, 1998) [hereinafter TCI Ordover-Willig Declaration].

57 The $p$-values for an $F$ test are .105 and .235 for the two regression specifications. Both $p$ values are well above normal significance levels.

58 The $p$-values for an $F$ test for the use of demographics is 0.63 for the first specification and 0.84 for the second specification. Neither $F$ statistic is anywhere near the 0.05 significance level. 
In summary, our econometric analysis rejects the hypothesis that narrowband access prices constrain broadband access prices. For antitrust purposes, therefore, broadband Internet access is not in the same antitrust market as narrowband Internet access based on the relationship of broadband Internet access prices to narrowband Internet access prices. Furthermore, the regression results indicate that Excite@Home is priced on a higher monthly basis than Road Runner by 11.6 percent. Thus, an expected result of the AT\&T-MediaOne merger would be an increase in the price of broadband Internet access for MediaOne's customers who currently use Road Runner. That price increase would harm consumers and would be a direct result of the merger.

3. The Qualitative Results of the Market Definition Tests Will Not Change Over the Relevant Time Horizon

One might argue that the force of our findings is limited because, while the early adopters of broadband Internet access are not likely to switch back after a broadband price increase, the second cohort of broadband Internet users will do so with greater frequency. In fact, there are other forces that will change over time to counteract the "late-adopters" effect. For example, the set of applications used by broadband subscribers will become less usable over narrowband platforms. That effect will reduce the likelihood that a late broadband adopter would switch back to a narrowband connection in the event of a five percent price increase, even if she were more price-sensitive than earlier broadband adopters.

One might also question whether an increase in the price of narrowband Internet access (that is, a reduction in the price difference between broadband and narrowband Internet access) will undermine our market definition analysis. Again, under this assumption, our determination of a separate broadband Internet access market will not be affected. If the access prices for narrowband and broadband converge, then the consumer's decision to switch back to narrowband after a broadband price increase will be less attractive. Stated another way, when the price of narrowband access rises, the value of leisure time saved by using a broadband connection will rise relative to the difference in out-of-pocket costs between a narrowband and broadband Internet connection. Hence, even more consumers will remain with their broadband Internet provider in the face of higher broadband access prices. With higher narrowband access prices, the share of marginal broadband customers will fall further below the "critical share" needed to render the broadband access price increase unprofitable. 


\section{Neither Digital Subscriber Line nor Satellite Internet Services Can Discipline Price in the Broadband Internet Market over the Relevant Time Horizon}

It is possible that at some point in the future new technologies will emerge, or existing technologies will be refined, in such a way that they will compete effectively with cable-based Internet services. In the antitrust setting, however, such speculation about new competition that may ameliorate a current concentration problem over an extended period has not been treated as sufficient reason to ignore the current problem. Thus, the Merger Guidelines specify the use of a two-year time horizon for evaluating the effects of a merger. ${ }^{59}$ When AT\&T's acquisition of MediaOne is analyzed in that framework, it becomes clear that after the merger AT\&T will have the ability to exercise market power over end users in the broadband Internet access market. In the sections that follow, we explain that, within the relevant two-year time horizon, neither DSL nor satellitebased Internet service will be able to offer close substitutes for cable-based Internet service. Hence, neither will be able to provide the price-disciplining constraint needed to protect consumer welfare.

Before describing the shortcomings of DSL and satellite connections, it is important to note that cable modems also face technical impediments. For example, cable users regularly complain about slowdowns caused by too many people on the system. ${ }^{60}$ Depending on the number of users in a neighborhood that are logged on, speeds can vary widely hour by hour. To alleviate this problem, several cable firms prevent users from hosting websites or other commercial uses on residential cable connections. ${ }^{61}$ This problem is not unique to cable providers, however, as many DSL providers have experienced similar complaints. ${ }^{62}$ In addition, not all cable companies have upgraded their equipment to offer cable modem service. For example, AT\&T cable Internet access is not yet available in large portions of downtown San Francisco. Finally, cable subscriber growth is limited because of unexpected parts shortages at Motorola and other equipment manufacturers. For example, Excite@Home blamed its 10 percent drop in growth on a temporary interruption in the supply of cable modems. ${ }^{63}$

59 See U.S. DEP'T OF JUSTICE AND FED. TRADE COMm'N, supra note 14 , \$ 3.2.

60 Dave Gusso, Full Speed Ahead Series: Tech-Times, St. Petersburg Times, Aug. 28, 2000, at $11 \mathrm{E}$.

61 Id.

62 For example, in August 2000 SBC was sued by residents of Nueces County, Texas, who claimed that SBC promised connections of up to $384 \mathrm{kbps}$ but actually limited connections to $128 \mathrm{kbps}$ for customers that used e-mail and newsgroups. Eric Ladley, DSL Threatens Excite@Home's Dominance, BROADBAND NETWORKING NEWS, Aug. 29, 2000.

63 Cable Modems Retain Market Lead But DSL Is Growing Faster, COMM. Dally, Aug. 2, 2000 , at *1. 
Certainly these problems, if not addressed adequately, would undermine a cable firm's ability to discriminate against unaffiliated content and conduit providers. We demonstrate below, however, that the problems afflicting DSL and satellite are more severe.

\section{Digital Subscriber Lines Will Not Provide Price Discipline Over the Relevant Time Horizon}

The slow deployment of DSL to date has limited its ability to discipline any price increase by a cable-based provider of broadband Internet access. To demonstrate the lack of availability of DSL relative to cable-based Internet access in the Washington, D.C. area, we entered zip codes (and telephone numbers, where appropriate) into the web sites of Bell Atlantic and cable providers that serve the Virginia suburbs. The results of our web searches by zip code are shown in tables and maps in Appendices 1 and 2, respectively. As of August 1999, cable-based providers already served 92 percent of the Virginia suburbs, while Bell Atlantic served only 46 percent. ${ }^{64}$ We also provide maps that summarize these results. Although the results of an analysis of a single metropolitan area are not definitive, the large differential in deployment between cable and DSL likely corresponds to broader trends in the marketplace.

Beginning in the 1970s, local exchange carriers began using a new type of loop-a digital loop carrier (DLC) - to reduce the cost of building new central offices to service growing suburbs and more densely populated urban areas. ${ }^{65}$ DLCs force digital transmission between the local loop and the central office. Unfortunately, DSL service cannot be supported by DLCs because DSL requires transceiver-to-transceiver signal consistency. To provide DSL over DLCs, the carrier must install digital subscriber line access multiplier ("DSLAM") termination at the DLC. This additional investment may impede DSL's ability to compete with cable-based broadband Internet access.

Although there are other solutions to the DLC problem besides DSLAM deployment, additional capital expenditures to overcome this problem cannot yet be avoided. This raises the cost of DSL deployment, and consequently, DSL service. The problem is exacerbated by the fact that DLCs have their greatest penetration in newer suburban subdivisions. These households are likely to be potential broadband Internet users. ${ }^{66}$

64 Our DSL count overestimates the actual coverage because we assume that if any ten-digit phone number within a zip code is covered, then the entire zip code is covered.

65 For a discussion of the difference between "old" and "new" loops, see STRATEGIS GROUP, supra note 16 , at $46-47$

66 Id. at 49. 
DLCs could limit DSL deployment in regions where DLCs have been used extensively. For example, almost 40 percent of BellSouth customers are connected through DLCs. ${ }^{67}$

Even in geographic markets where customers are connected with "old" loop technology, DSL deployment is constrained by different technical impediments. DSL is sensitive to the distance that transmissions must travel between the home and central office. According to a study commissioned by the Competitive Broadband Coalition, DSL in its current form faces "an absolute limit of 18,000 feet for the copper segment." ${ }^{168}$ That impediment will severely limit DSL's ability to impose price discipline on cable-based providers of Internet access in areas located several miles from the central office. According to GTE, nearly 35 percent of its telephone connections (and hence potential broadband customers) are beyond 18,000 feet of a central office. ${ }^{69}$

Even if DSL providers were to overcome their technological limitations, significant regulatory barriers prevent them from competing effectively against the cable broadband providers. The regional Bell Operating Companies (RBOCs), which are the primary providers of DSL, operate within an entirely different regulatory environment than their cable competitors. First, the RBOCs are excluded entirely from the core backbone market. Given the high congestion of backbones, telephone companies must accept terms from backbone providers that may be worse than the standalone costs of backbone self-provision. Second, RBOCs may distribute, but not manufacture, equipment used on customer premises. ${ }^{70}$ Therefore, unlike cable providers such as AT\&T, the RBOCs cannot collaborate with equipment vendors. Third, RBOCs face separate-subsidiary requirements that may make it more expensive to provide Internet search engines or content of any kind. ${ }^{71}$ Again, unlike cable firms that may completely integrate portals such as Yahoo! or Excite, RBOCs must set up fully separate subsidiaries for that purpose. Fourth, the Telecommunications Act of 1996 requires $\mathrm{RBOCs}$ to unbundle their network services ${ }^{72}$ at rates that have so far

67 Strategis reports that 15 percent of Bell Atlantic's customers are connections through DLCs, while 30 of GTE's customers rely on "new" loops. Id. at 50.

68 LeE L. SElWyn, Patricia D. KRAVtin \& SCotT A. Coleman, Competitive Broadband COALITION, BUILDING A BROADBAND AMERICA: THE COMPETITIVE KEYS TO THE FUTURE OF THE INTERNET 61 (1999).

69 Declaration of Dale E. Veeneman and Evertt H. Williams, on behalf of GTE Corp. Applications for Consent to the Transfer of Control of Licenses, MediaOne Group, Inc., Transferor, to AT\&T Corp., Transferee, CS Docket No. 99-251, ๆ 10 (filed Aug. 23, 1999) [hereinafter Veeneman \& Williams Declaration].

$70 \quad$ See 47 U.S.C. § 273(a) (1994).

71 See id. $\$ 274(\mathrm{a})(1994)$.

72 See id. \&251(c)(3) (1994). 
been based on the long-run incremental costs of providing them. ${ }^{73}$ The FCC has indicated its policy of extending unbundling requirements to broadband Internet services. ${ }^{74}$ Fifth, the RBOCs are currently barred from providing interLATA (local access and transport area) services except in New York and Texas, ${ }^{75}$ which means they are prevented from creating "region centered points of presence that would allow them to take advantage of economies of scale in data service." ${ }^{, 76}$ The asymmetric regulatory treatment of the RBOCs with respect to cable providers prevents DSL from being an effective competitor in the broadband Internet access market for residential customers.

\section{Satellite Internet Services and Wireless Technologies Will Not Discipline Price over the Relevant Time Horizon}

Opponents of the recent local push to require open access point to the AOL-Hughes alliance to develop satellite Internet services as a means of providing sufficient protections against the exercise of market power by cable providers. ${ }^{77}$ For example, Brian Roberts, president of Comcast, recently argued that "AOL's investment [in DirectTV] undercuts the notion that there won't be true competition for broadband Internet access and undercuts the need for government involvement." ${ }^{, 8}$ Although the AOLHughes alliance will certainly accelerate the development of satellite-based services, ${ }^{79}$ those services are not likely to provide the price-disciplining constraint on cable-based systems over the relevant time horizon. Current subscribers to the AOL-Plus broadband access over DirectTV's satellite network must upload information over standard (narrowband) telephone lines at maximum speeds of $56.6 \mathrm{Kbps} .^{80}$

73 See id. $\$ 252(\mathrm{~d})(1)(\mathrm{A})(\mathrm{i})$ (1994).

74 See Deployment of Wireline Services Offering Advanced Telecommunications Capability, Memorandum Opinion and Order, and Notice of Proposed Rulemaking, CC Docket No. 98-147, 13 F.C.C.R. 24,011, at 24,017-18 (released Aug. 7, 1998).

75 See 47 U.S.C. $\$ 271$ (a) (1994). It should be noted that, unlike the RBOCs, GTE is free from section 271 restrictions. The increased efficiency of GTE's DSL operation relative to other RBOCs' DSL operations is a good indicator of the regulatory costs imposed on the other RBOCs by section 271 . For information on how GTE uses frame relay to increase efficiency, see Veeneman \& Williams Declaration, supra note 69 , $116-7$.

76 STRATEGIS GROUP, supra note 16, at 201.

77 As part of the arrangement, $\mathrm{AOL}$ will invest $\$ 1.5$ billion in General Motors (GM) equity security. GM will immediately invest the money in a security of Hughes, where the funds will be employed to implement the strategic alliance between AOL and Hughes. In retum, Hughes will make a commitment to market AOL TV and AOL-Plus and accelerate the growth of DirectTV and DirectPC. See, e.g., AOL to Invest \$1.5 Billion in Hughes Electronics: Deal to Combine Internet Services with Digital TV Systems; High Technology, BALT. SuN, June 22, 1999, at 1D.

78 Peter Elstrom, Ronald Grover, and Catherine Yang, Whose Cables Are They?, BusINESS WEEK, July 5, 1999, at 24.

79 Jan Howells, Intel and Hughes Collaborate on Digital Satellite Set-Top Boxes, NEWSWIRE, June 22,1999 , at *1.

80 GM: $A O L$ and Hughes Electronics Form Alliance to Market Digital Entertainment and 152 
When asked to compare cable with satellite-based broadband systems, Rupert Murdoch, chairman of Fox Networks, remarked "there is nothing satellite can do at the moment cable can't do a lot better." ${ }^{.81}$ In the following paragraphs, we give context to Murdoch's assessment and thereby demonstrate why satellite-based services cannot be relied upon to provide a price-disciplining effect on cable-based systems over the relevant time horizon.

Broadband communications over satellite is expected to be only oneway until at least 2002. Satellite-based broadband Internet service is not currently a close substitute to cable-based Internet access because, unlike cable systems, it provides broadband connection in only one direction, from the satellite to the user's computer. Hughes, the owner of DirectTV, is developing a new satellite system named Spaceway, which could provide broadband connections both ways. Unfortunately, this closer substitute for cable-based Internet service will not be available until $2003 .^{82}$ Even the oneway high-speed capability of satellite-based service is inferior with respect to customer connection to the Internet. Unlike the broadband services offered by cable and telephone companies, AOL-Plus subscribers using DirectPC will not be connected continuously to the Internet. ${ }^{83}$ The inconvenience to the consumer of having to dial-in each time to establish a connection will certainly influence the decision-making process of potential customers. ${ }^{84}$

Satellite Internet services entail higher up-front and monthly service fees than cable internet providers. Surprisingly, DirectPC will not even have an advantage with respect to existing DirectTV subscribers, since customers wanting to add broadband Internet to their package must purchase a separate dish. ${ }^{85}$ As of June 1999 , roughly 40,000 customers had subscribed to DirectPC. ${ }^{86}$ The costs of the DirectPC dish are about $\$ 200$. Unlike the monthly fee charged by cable providers, DirectPC is priced on an hourly basis. ${ }^{87}$ For example, high-volume users can expect to pay as much as $\$ 129.99$ per month for the service. ${ }^{88}$ The combination of the up-front

\footnotetext{
Internet Services, M2 PRESSWIRE, June 22, 1999, at *1.

81 John Durie, The Battle for Broadband Control, AUSTL. FIN. REV., June 22, 1999, at 64.

82 AOL to Invest \$1.5 Billion in Hughes Electronics; Deal to Combine Internet Services with Digital TV Systems; High Technology, supra note 77.

83 Jon Healey, Leading High-Tech Companies Pledge to Expand Wireless Internet Service, SAN JOSE MERCURY NEWS, June 22, 1999.

84 STRATEGIS GROUP, supra note 16 , at 76.

85 Healey, supra note 83.

86 Lee Hall, AOL Takes Direct Path Around Cable Hurdle, Electronic MediA, June 28, 1999 , at $* 1$.

$87 \quad$ Id.

88 Id. ("The company offers three levels of service: $\$ 29.99$ per month for 25 hours, $\$ 49.99$ for 100 hours per month, and $\$ 129.99$ for 200 hours per month. If you go over your monthly time limit, you pay $\$ 1.99$ for each additional hour.")
} 
investment and the monthly price makes DirectPC substantially more expensive than cable-based Internet service. ${ }^{89}$

Looking further into the future, one cannot ignore the potential impact of both current- and next-generation wireless Internet access. For example, 128 -kbps Metricom/Ricochet wireless modem access is currently available in certain markets, ${ }^{90}$ and although its top speed is below the $200-\mathrm{kbps}$ broadband requirement set by the FCC, it may nonetheless have some disciplining effect on cable modem providers. Moreover, third-generation wireless technology promises to deliver wireless Internet access speeds of up to $2 \mathrm{Mbps}$ to indoor home users and is expected to be implemented in the United States in a few years. To the extent that broadband consumers utilize a wireless device and a home-unit for different purposes-a likely possibility given the different needs of traveling broadband users-the advent of wireless technologies for broadband access may not, by itself, undermine a cable provider's efforts to extend its power into the broadband content and broadband e-commerce markets.

\section{E. The Broadband Internet Services Market Is Highly Concentrated}

Even under the generous assumption that DSL and satellite have the same "future competitive significance" as cable-based broadband service, ${ }^{91}$ the broadband Internet access market is extremely concentrated.

1. Standard Antitrust Analysis Demonstrates that the Broadband Internet Services Market Is Highly Concentrated

In any given local market, there can be only one cable-based Internet provider as a result of the AT\&T-MediaOne merger. ${ }^{92}$ Moreover, over the relevant time horizon, there will be only a few DSL and satellite providers. Furthermore, a concentration index based on the current number of subscribers potentially overstates the competitive significance of non-cable broadband providers, because it ignores the large first-mover advantages of cable firms.

As we described earlier, broadband Internet services markets are local in nature. Measures of concentration at a local level are not readily available,

\footnotetext{
89 SELWYN, KRAVTIN \& COLEMAN, supra note 68 , at 77.

90 For a review of Metricom/Richocet's offerings, visit the company's website at http://www.metricom.com.

91 See U.S. DEP'T OF JUSTICE AND FED. TRADE COMM'N, supra note $14, \S 1.411$. The Guidelines recommend that one use the best proxy for "future competitive significance" when analyzing market concentration. Califomia.

92 Except, of course, in the limited overbuild situations that exist, such as Thousand Oaks, 
however, because carriers only provide information on subscribers at the national level in their quarterly financial filings. It is only possible to draw inferences about the average local level of concentration based on a nationwide measure of concentration. Table 3 shows several estimates of the market share for cable modems and DSL.

TABLE 3: MARKeT SHARE EstimateS

MADE BETWEEN JUNE 1, 2000 AND AUGUST 31, 2000

\begin{tabular}{lcccc}
\hline Consultancy & $\begin{array}{c}\text { Cable } \\
\text { Subscribers }\end{array}$ & $\begin{array}{c}\text { DSL } \\
\text { Subscribers }\end{array}$ & $\begin{array}{c}\text { Relevant } \\
\text { Date }\end{array}$ & $\begin{array}{c}\text { Cable } \\
\text { Share }\end{array}$ \\
\hline Yankee & $3,500,000$ & 900,000 & $12 / 31 / 2000$ & $79.5 \%$ \\
Group/Kagan $^{(1)}$ & & & & \\
TeleChoicec $^{(2)}$ & $3,000,000$ & $1,400,000$ & $8 / 29 / 2000$ & $68.2 \%$ \\
Forrester $^{(3)}$ & $2,227,000$ & 869,000 & $5 / 31 / 2000$ & $71.9 \%$ \\
Research $^{(3)}$ & & & & \\
AVERAGE & & & & $73.2 \%$ \\
\hline
\end{tabular}

Sources: (1) David Gusso, Full Speed Ahead Series: Tech Times, ST. Petersburg Times, Aug. 28, 2000, at 11E. (2) Eric Ladley, DSL Threatens Excite@Home's Dominance, BRoadBand NeTworking News, Aug. 29, 2000. (3) Cable Modems Retain Market Lead, But DSL is Growing Faster, COMM. DAILY, Aug. 2, 2000, at *1.

As Table 3 shows, cable's market share was, on average, estimated to be 73.2 percent as of the third quarter of 2000. DSL still lags far behind cable modems and is not closing the gap as quickly as expected-cable's share was 83.6 percent in the third quarter of $1999 .{ }^{93}$ It is important to note two items when considering broadband market share. First, the relevant market for the purpose of our discussion is the residential broadband access market. Because the above numbers include both residential and business sectors, and because cable has little to no presence in the business sector, the market share for DSL providers is overstated. ${ }^{94}$ According to TeleChoice, on average, 84 percent of an incumbent local exchange carrier's DSL subscribers are residential. ${ }^{95}$ Using that factor to adjust the market share in Table 3, the average residential cable market share across the three estimates

93 Cable Modem Customer Count Tops I Million, CABLE DataCom NEWS, August 1999, at 2, available at http://www.cabledatacomnews.com/aug99/aug99-1.html.

94 According to Cynthia Brumfield, president of Broadband Intelligence, "cable doesn't compete in the small business market. It's really DSL's game to win or lose." Cable Modems Retain Lead But DSL is Growing Faster, COMM. DAILY, Aug. 2, 2000, at *1. Furthermore, DSL companies such as Covad have concentrated almost solely on the business market, with very few sales into the residential market.

95 John Edwards, DSL on the heels of cable, UPSIDE TODAY, Oct. 10, 2000, at 3, at http://www. upside.com/texis $/ \mathrm{mvm} /$ news $/$ story? id=39dbce 700 . 
would increase to 76.5 percent $=0.732 /(0.732+0.84 \times(1.0-0.732))$. According to an FCC study released in October 2000, the ratio of cable modems to DSL for "residential and small business high-speed lines" at the end of June 2000 was 2.5 to $1{ }^{96}$ Second, the threat of discrimination against unaffiliated broadband conduits or broadband content providers remains, albeit at a diminished level, even as the downstream market share of the vertically integrated firm approaches 50 percent. Stated differently, the traditional models of discrimination do not depend on the vertically integrated firm obtaining some critical level of downstream market share. ${ }^{97}$ By discriminating against the downstream rival the vertically integrated firm can raise its rival's cost by weakening its bargaining position with respect to nonaffiliated upstream suppliers. Of course, a larger downstream market share enhances the vertically integrated firm's incentive to engage in discrimination, ${ }^{98}$ but a dominant market share is not a necessary condition for discrimination to be effective.

2. High Startup Costs Constrain the Fringe Participants' Ability to Discipline Price in the Broadband Internet Access Markets over the Relevant Time Horizon

Some commentators include wireless and electric utilities as "viable technologies and service providers in the broadband race." with the Merger Guidelines, we assess the likelihood that those "uncommitted" entrants would "enter rapidly into production or sale of a market product in the market's area, without incurring significant sunk costs of entry and exit." ${ }^{100}$ Based on our analysis of the state of development of electric utilities and wireless providers of broadband, we do not believe that those technologies can be relied upon to instill price discipline in the broadband market.

With respect to electric utilities, no potential entrants will be positioned to instill price discipline over the next two years. For example, Electric Lightwave, an aggressive entrant in the broadband market, has been

96 Press Release, Fed. Communications Comm'n, High Speed Services for Internet ServicesSubscribership as of June 30, 2000 (released Oct. 31, 2000), at Table 3 (on file with the Yale Journal on Regulation).

97 See, e.g., Jeffrey Church and Neil Gandal, Systems Competition, Vertical Merger and Foreclosure, 9 J. ECON. \& MGMT. STRATEGY 1 (2000); and Janusz A. Ordover, Garth Saloner, and Steven C. Salop, Equilibrium Vertical Foreclosure, 80 AM. ECON. REV. 127-142 (1990).

98 See, e.g., Daniel L. Rubinfeld \& Hal J. Singer, AOL-Time Warner: Vertical FORECLOSURE IN THE BROADBAND ACCESS INDUSTRY (Working Paper 2000) (on file with authors).

99 Commissioner Michael K. Powell, Remarks before the Chicago Chapter of the Federal Communications Bar Association 5 (June 15, 1999) (transcript available on the FCC web site, $a t$ http://www.fcc.gov/speeches/Powell/spmk0902.html).

100 U.S. DEP'T OF JUSTICE AND FED. TRADE COMM'N, supra note 14, § 1.0. 
projected to reach only 7,500 route miles by the end of $2000 .^{101}$ Thus, the electric utilities' impact on the market for broadband services will not be realized for several years.

Wireless entrants in the broadband residential Internet market likewise will not compete effectively with cable-based broadband services for years to come. The prices of the first wireless local loop (WLL) providers in the United States are substantially higher-and the speeds lower-than cable alternatives. For example, Clearwire Technologies offers a near-line-of-sight, point-to-multipoint, symmetrical WLL service with speeds of up to $512 \mathrm{Kbits} / \mathrm{sec}$ (symmetrical). ${ }^{102}$ Clearwire's Internet service is priced between $\$ 95$ to $\$ 495$ per month. In April 1999, Clearwire rolled out its first commercial deployment of the service in Dallas. ${ }^{103}$ Other WLL products include WavePath's MMDS-based iSpeed wireless Internet access service (priced between $\$ 150$ per month and $\$ 400$ per month), ${ }^{104}$ and Wireless One's Warp One (priced between $\$ 150$ and $\$ 890$ per month). ${ }^{105}$

Wireless local loop providers face several obstacles to compete effectively in broadband markets. First, wireless carriers face high costs of infrastructure components-some broadband wireless local-loop contracts sell for $\$ 600$ to $\$ 900$ per line. ${ }^{106}$ Second, WLL faces speed and distance limitations. ${ }^{107}$ Third, wireless deployment lacks a cohesive set of standards governing the technology. ${ }^{108}$ Fourth, WLL is threatened by security concerns, as signals are sometimes intercepted. ${ }^{109}$ Fifth, if there are too many users on a channel, congestion may arise. ${ }^{110}$ As one analyst suggests, WLL cannot be relied upon to instill price discipline in the broadband Internet marketplace over the relevant time horizon: "While wireless technology could eventually provide an effective solution for local-loop access, its relatively slow adoption rate has cast some doubt as to whether it will be a viable alternative in the near future."111 According to the Strategis Group, wireless providers are not expected to have a serious impact on the broadband market until 2003. ${ }^{112}$

101 Philip Carden, Meet the New-Age Carriers, NETwORK COMPUTING, July 12, 1999, at 40.

102 Information downloaded from company web site, at http://www.clearwire.com (last visited Aug. 18, 1999).

103 Elizabeth Clark, Special Report: Wireless, NETwORK MAGAZINE, June 1, 1999, at 37.

104 Information downloaded from company web site, $a t$ http://www.wavepath.com (last visited Aug. 18, 1999).

105 Information downloaded from company web site, at http://www.warpone.com (last visited Aug. 18, 1999).

106 Id.

107 Clark, supra note 103.

108 Id.

109 Id.

110 Id

111 Id. (emphasis added).

112 STRATEGIS GROUP, supra note 16, at 7. 
II. The Anticompetitive Effects of Expanding the Cable Footprint of a Vertically Integrated Cable Provider

Full-service broadband providers like AT\&T and MediaOne must integrate four inputs of broadband service: (1) broadband content (e.g., streaming video and audio, movies, video conferencing, interactive games), (2) the aggregation of broadband content and complementary services (e.g., chat rooms, instant messaging) by a broadband portal, (3) connectivity to the Internet supplied by a broadband Internet service provider, and (4) highspeed transport from the home to the ISP supplied by a cable provider, telephone company, or other broadband conduit provider. Both AT\&T and MediaOne offer all four components. Through its ownership in Time Warner Entertainment, MediaOne has access to an attractive portfolio of broadband content. Through its ownership of TCI, AT\&T has access to the content portfolio of Liberty Media. The AT\&T-MediaOne merger can be viewed as a merger of two vertically-integrated broadband providers seeking to expand their combined cable footprint.

\section{A. A Larger Footprint Increases the Incentive and Opportunity to Discriminate against Unaffiliated Broadband Content Providers}

From these market definitions follow two anticompetitive strategies that a vertically integrated firm, offering both broadband transport and portal services, could profitably pursue. First, an integrated provider could engage in conduit discrimination-insulating its own conduit from competition by limiting its distribution of affiliated content and services over rival platforms. Conduit discrimination could involve a range of anticompetitive strategies, from refusing to distribute an affiliated portal over competing conduits, to making marquis content available only to customers using an affiliated conduit. Second, an integrated provider could engage in content discrimination-insulating its own affiliated content from competition by blocking or degrading the quality of outside content. Content discrimination could involve a range of strategies, from blocking outside content entirely, to affording affiliated content preferential caching treatment. ${ }^{113}$ In the sections that follow, we explain how an increased cable footprint increases the incentives to engage in both forms of discrimination.

113 Senate Antitrust Panel Leaders Worried ISPs Can Use Routers, Caching to Favor Affiliates, TR DAILY, May 10, 2000, at http://www.tr.com/tronline/trd/2000/td051000/td051000.htm (citing a cablesystem manufacturer's white paper that touted the system's ability to "promote and offer your own or partners' services with full-speed features to encourage adoption of your services, while increasing network efficiency"). 
1. The Firm's Incentive to Discriminate Against Unaffiliated Broadband Content and Conduit Providers Increases with the Size of Its Footprint

Conduit discrimination (against unaffiliated broadband conduits such as DSL) is costly, as a firm engaging in conduit discrimination will forgo revenues from content distribution over rival platforms. There are potentially countervailing benefits, however, because with conduit discrimination, customers will perceive the cable conduit as more valuable. This, in turn, will increase the demand for cable transport relative to other forms of transport. Hence, a cable broadband provider will engage in conduit discrimination if the gain from additional access revenues from broadband users offsets the loss in content revenues from narrower distribution.

If a cable broadband transport provider controls particular content but only has a small fraction of the national broadband transport market, that provider would have little incentive to discriminate against rival broadband transport providers outside of its cable footprint. The intuition is straightforward: out-of-franchise conduit discrimination would inflict a loss on the cable provider's content division, while out-of-region cable providers would be the primary beneficiaries of harm done to DSL competitors. To capture the gains from such discrimination, the vertically integrated cable provider must have a cable footprint in which to distribute its broadband portal service, either through direct ownership or through an arrangement to share the benefits of foreclosure with other cable providers.

Content discrimination (against unaffiliated broadband content) is equally costly, as a firm engaging in content discrimination will forgo revenues from customers who insist on accessing the content generated outside the cable firm. For example, to insulate its Internet radio service, a vertically integrated broadband provider could refuse to distribute music from competing record companies. This form of discrimination would benefit the cable provider by enhancing the position of its affiliated content providers in the national market by denying unaffiliated content providers critical operating scale and insulating affiliated content providers from competition. Content discrimination would thus allow the vertically integrated content provider to earn extra revenues from its own portal customers who would have fewer opportunities to interact with competing outside content.

To the extent that cable transport providers compete against DSL and other broadband transport providers, the reduction in revenues from lost customers will be greater. Further, note that content discrimination does not require a complete denial of access to outside content. Nevertheless, even less severe strategies (for example, providing unequal caching treatment to 
unaffiliated content providers) may inflict some loss on the downstream transport division because some customers may still prefer to switch transport providers than suffer slower access to outside content. Hence, a vertically integrated broadband provider will engage in content discrimination if the gain from additional portal, content, and advertising sales offsets the reduction in broadband access revenues resulting from lost broadband subscribers.

2. Cable Providers Have the Ability to Discriminate Against Unaffiliated Content Providers in Several Ways

There are several ways in which a vertically integrated broadband provider can discriminate against unaffiliated content providers. First, it can give preference to an affiliated content provider by caching its content locally. As the Director of GTE's Business Development for Broadband Data Services has explained:

Within the ISP's point of presence linked to the regional router, the affiliated ISP is able to cache preferred content for the fastest possible delivery to customers (though this may be done elsewhere in the ISP's very-high-speed national backbone). In closed systems, cable modem customers do not need to access the public Internet to reach content supplied directly by their cable provider's affiliated ISP. ${ }^{114}$

Such preferential treatment ensures that affiliated content can be delivered at faster speeds than unaffiliated content.

Second, a vertically integrated broadband provider can limit the duration of streaming videos of broadcast quality to such an extent that they can never compete against cable programming. Stated more generally, a vertically integrated firm like AT\&T can block any competing content that it wants to. Professors Ordover and Willig, however, turn that anticompetitive practice upside down: "We also understand that there are pro-competitive explanations for limits on cable-delivered Internet video streaming including the need, inherent in the shared nature of the cable plant, to ensure that a few bandwidth 'hogs' do not slow down and degrade the experience of all users." 115 Under traditional antitrust principles, AT\&T's limitation on the duration of streaming video exhibits the "hallmarks of anticompetitive behavior [that] place upon [it] a heavy burden of establishing an affirmative defense which competitively justifies this apparent deviation from the

114 Declaration of Albert Parisian, on behalf of GTE Corp., Applications for Consent to the Transfer of Control of Licenses, MediaOne Group, Inc., Transferor, to AT\&T Corp., Transferee, CS Docket No. 99-251, at ๆ 8 (filed Aug. 23, 1999).

115 MediaOne Ordover-Willig Declaration, supra note 1, ๆ 117 (emphasis added). 
operations of a free market." 116 Whether AT\&T can satisfy that heavy burden depends on whether its time limit for streaming video is indeed necessary to make its cable network operate efficiently, and on whether that objective could be accomplished by less restrictive means. ${ }^{117}$ As one court put it, "a factor in determining the reasonableness of an ancillary restraint is the 'possibility of less restrictive alternatives' which could serve the same purpose." 118 Clearly, a less restrictive allocation mechanism (such as prices or overall caps on per customer usage) could be designed to ration efficiently the capacity of AT\&T's cable network to deliver streaming video.

Third, a vertically integrated firm such as AT\&T or AOL-Time Warner could impose proprietary standards that would render unaffiliated content useless. To dismiss that claim, Professors Ordover and Willig incorrectly argue that all broadband content can be supported by narrowband applications:

Indeed, even if AT\&T had 100 percent of the broadband customers, that would give it no ability either to impose proprietary standards or to tie up content providers with exclusive contracts. AT\&T would still "control" only a tiny fraction of the consumers of content sites ..... And, establishing proprietary standards that limit the content available to its customers is likely the surest way to discourage customers from making the switch [to AT\&T's broadband network]. ${ }^{11}$

But by focusing on the decision to switch to AT\&T's network, Professors Ordover and Willig fail to address whether AT\&T's proprietary standards will prevent broadband customers from switching from AT\&T's cable network. For the purpose of antitrust analysis, the question that Professors Ordover and Willig ignore is the relevant one.

The academic literature on standards and network externalities provides theoretical and empirical support for the conjecture that AT\&T could impose proprietary standards that would raise the switching costs for its subscribers and stifle competition in vertically related software markets. Applied to the present case, the positive network externality is the increasing value of AT\&T's broadband network as more of its network is utilized. ${ }^{120}$ Because

116 National Collegiate Athletic Ass'n v. Board of Regents of the Univ. of Okla., 468 U.S. 85 , 113 (1986) [hereinafter NCAA]. See also National Soc'y of Prof'l Engineers v. United States, 435 U.S. 679, 692-96 (1978).

117 See NCAA, 468 U.S. at 102-04, 117-20.

118 Los Angeles Mem'l Coliseum Comm'n v. National Football League, 726 F.2d 1381, 1396 (9th Cir. 1984) (quoting North Am. Soccer League v. National Football League, 459 U.S. 1074, 1074 (1982) (Rehnquist, J., dissenting)).

119 MediaOne Ordover-Willig Declaration, supra note 1, ๆ 129 (emphasis in original).

120 See Michael L. Katz \& Carl Shapiro, Network Externalities, Competition and Compatibility, 75 AM. ECON. REV. 424 (1985); and Michael L. Katz \& Carl Shapiro, Systems Competition and Network Effects, J. ECON. PERSP., Spring 1994, at 93. 
AT\&T is the first to the broadband residential marketplace and because the marginal cost of writing software for a second standard is substantial, software designers will likely write applications that are exclusively compatible with AT\&T's standard, thereby increasing the value of AT\&T's broadband network relative to other broadband networks. Those positive externalities are self-reinforcing in the sense that consumers will recognize AT\&T's advantage and subscribe to AT\&T's broadband network in greater numbers. Empirical studies suggest that there are positive demand-side feedback effects between hardware and software when they operate on exclusive standards. ${ }^{121}$ Neil Gandal, Michael Kende, and Rafael Rob have found that the availability of compatible software had a significant and positive effect on the adoption of compact disc players, in part because compact disc players were not compatible with existing audio standards. ${ }^{122}$ Once the AT\&T standard has been established, AT\&T will be able to exercise market power over customers and those companies trying to reach its customers. ${ }^{123}$

\section{The Decreased Variety in Content Will Cause Substantial Consumer Welfare Losses}

We have demonstrated that a vertically integrated broadband provider will have strong incentives to discriminate against unaffiliated content providers despite the fact that consumers value diversity in broadband content. Because most broadband content will compete with cable programming, it is possible to infer the extent to which consumers value variety in broadband content (and hence the extent of their welfare loss when denied such variety) based on consumers' value of diversity in cable programming content. Fortunately, economists have already empirically estimated the value that cable-programming consumers place on variety in content. In 1996, Robert Crandall of the Brookings Institution and (now FCC Commissioner) Harold Furchtgott-Roth estimated a multinomial logit model

121 See, e.g., Thomas Cottrell, Standards and the Arrested Development of Japan's Microcomputer Software Industry, in THE INTERNATIONAL COMPUTER SOFTWARE INDUSTRY: A COMPARATIVE STUDY OF INDUSTRY EVOLUTION AND STRUCTURE 131-164 (David C. Mowery ed., 1996); and Neil Gandal, Competing Compatibility Standards and Network Externalities in the PC Software Market, 77 REV. ECON. \& STAT. 599 (1995).

122 Neil Gandal, Michael Kende \& Rafael Rob, The Dynamics of Technological Adoption in Hardware/Software Systems: The Case of Compact Disc Players, 31 RAND J. ECON. 43 (Spring 2000).

123 Stanley M. Besen, The Standards Processes in Telecommunication and Information Technology, in STANDARDS, INNOVATION AND COMPETITIVENESS: THE POLITICS AND ECONOMICS OF STANDARDS IN NATURAL AND TECHNICAL ENVIRONMENTS 136-46 (Richard Hawkins, Robin Mansell and Jim Skea eds.,1995); Cottrell, supra note 121, at 131-64; and Joseph Farrell \& Garth Saloner, Installed Base and Compatibility: Innovation, Product Preannouncements and Predation, 76 AM. ECON. REV. 940 (1986). 
of the demand for cable services and used the results to estimate the effects on consumer welfare of changes in service characteristics. ${ }^{124}$ They found that consumers would be willing to pay an additional $\$ 1.03$ per month for carriage of an additional basic satellite channel. ${ }^{125}$ Using their estimates of willingness to pay for diversity in content, Crandall and Furchtgott-Roth calculated that "approximately 100 million U.S. households in 1992 would have been willing to pay $\$ 6.5$ billion to obtain the 1992 service-rate combination [with greater programming choices] rather than the 1983-84 combination [with fewer programming choices]." ${ }^{126}$ Applied to the present case, it would appear that consumers would suffer very large welfare losses if they were denied programming choices over the Internet.

AT\&T's (and previously TCI's) traditional cable strategy has been to use its market power in the delivery of programming to expand its control over the programming itself. The implementation of that strategy through the AT\&T-MediaOne merger will thus harm consumers by limiting their choices in broadband content. Because Professors Willig and Ordover narrowly focus on the direct harm to consumers from the merger, they foresee no anticompetitive effects:

If the proponents of forced access are right in predicting that future consumers will so prefer cable-delivered online services that alternatives will wither on the vine, then AT\&T and MediaOne, each acting alone, would enjoy the same "power" over the customers in their respective service areas as the proponents of forced access posit for the combined entity. ${ }^{127}$

Professors Ordover and Willig overlook the indirect consumer harm that will result from less broadband content (after AT\&T discriminates against unaffiliated broadband content providers).

\section{B. The Early Leader in Broadband Access Will Enjoy "Lock-in" Effects}

Defenders of a hands-off approach to broadband open access suggest that broadband competition from DSL and satellite providers over the next several years will constrain a cable provider's ability to exercise market

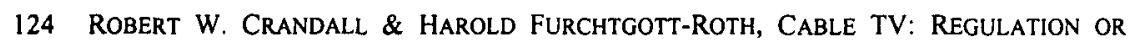
COMPETITION? 50-55 (1996).

125 Likewise, the authors found that consumers would be willing to pay an additional $\$ 1.35$ per month for carriage of an additional basic broadcast channel. Id. at 56 .

126 Id. at 58.

127 MediaOne Ordover-Willig Declaration, supra note 1, \68. 
power in vertically related markets. ${ }^{128}$ Even though residential DSL penetration will not be anywhere near that of cable modems, by that time the broadband race may be over. Due to the nature of network industries in general, the early leader in any broadband Internet access may enjoy a "lockin" of customers and content providers - that is, given the high switching costs for consumers associated with changing broadband provider (for example, the cost of a DSL modem and installation costs), an existing customer would be less sensitive to an increase in price than would a prospective customer. ${ }^{129}$ Hence, given a change in the cable operator's price or policy toward unaffiliated content, an existing cable customer could be locked into an arrangement that she might not consider optimal. As applied to the present case, a cable provider could wield significant market power in the broadband Internet access market so long as it can establish an early lead in acquiring customers. Hence, any promise of DSL or satellite competitiveness in the new millennium may be futile. ${ }^{130}$

As explained above, consumer lock-in can derive from content and software producers' choices given the initial choices of broadband customers. Because they represent such a small portion of the consumer's total switching costs, the out-of-pocket costs of a cable modem are only a very small portion of the overall switching analysis.

Finally, defenders of a hands-off approach claim that a cable provider will never be able to exercise market power on broadband end-users because it has no means of identifying the minority of potential users of broadband for whom "narrowband services is not an acceptable substitute, and thus has no means of charging higher prices to the minority." 131 A cable provider, however, need not be able to identify or target inframarginal customers to be able to exercise market power. ${ }^{132}$ Whether one product is an "acceptable substitute" for another product to a given consumer depends on price as well as product attributes. The underlying data for narrowband access prices and the econometric results demonstrate that, despite wide variation in the price of narrowband access, the price of Excite@Home does not vary with respect

128 The FCC also mistakenly places much confidence in narrowing penetration rates between cable modems and DSL by 2007. See BROADBAND TODAY, supra note 13, at 46 . Predictions that far into the future are generally worthless for the purpose of antitrust analysis.

129 As demonstrated by its recent case against Microsoft, network effects appear to be an important antitrust concern for the Department of Justice. Although reasonable minds may differ on the significance of network effects, it is incumbent on policy analysts and economists to consider the issue seriously. See generally Howard A. Shelanski \& J. Gregory Sidak, Antitrust Divestiture in Network Industries, 68 U. CHI. L. REV. (forthcoming Winter 2001).

130 For an in-depth analysis of lock-in, network, and positive feedback, see HAL R. VARIAN \& CARL SHAPIRo, INFORMATION RULES: A STRATEgIC GUIDE TO THE NETWORK ECONOMY (1998)

131 MediaOne Ordover-Willig Declaration, supra note 1, I 93 (emphasis omitted).

132 See Hausman, Leonard \& Vellturo, supra note 15 , at 373 , for a discussion of price discrimination with imperfect targeting of consumers. 
to the price of narrowband access. Thus, the narrowband access price does not constrain the price of broadband access. Price discrimination is consequently unnecessary to exercise market power in broadband access because a significant proportion of consumers are willing to pay a "premium price" for broadband access. AT\&T and other cable MSOs find it profitmaximizing to charge approximately $\$ 40$ per month for broadband access, regardless of the actual price of narrowband access in a particular geographical region. ${ }^{133}$

\section{Regulatory Review of Open Access and Market Definition}

Both the DOJ and the FCC reviewed the proposed merger of AT\&T and MediaOne in the early months of 2000 . In its review of the relevant markets, the DOJ differentiated the markets for narrowband and broadband Internet access. The DOJ found that " $[t]$ he vast majority of residential" Internet users employed narrowband technologies that allow them to send and receive data at rates of 56 kilobits per second or less, but that "[a] rapidly growing number of residential users" use " broadband' networks and technologies" to receive data at rates up to 25 times the capacity of narrowband services. ${ }^{134}$ The DOJ noted that the upstream data transmission rates of competing broadband technologies differed widely.

The DOJ concluded that the market for broadband services would continue to expand rapidly. In particular, the DOJ found that "many firms are developing content that will be particularly attractive to residential broadband consumers." 135 In the future, the DOJ noted, streaming video, interactive entertainment, and other data-intensive Internet services will further differentiate the market for Internet access. Because of the increased differentiation of broadband and narrowband product markets, the DOJ concluded, narrowband Internet content "that will be viewed by the general mass of Internet users - a substantial majority of which are narrowband users - are not a good substitute for [content] that will be widely and exclusively viewed by broadband users." 136

The DOJ considered broadband content to be differentiable from narrowband content, such that "[a] relevant product market affected by this transaction is the market for aggregation, promotion, and distribution of

133 In actuality, Professors Ordover and Willig have their facts wrong because MediaOne does price discriminate for broadband Internet access. Depending on the particular cable tiers chosen, MediaOne varies the price of its broadband cable access. It is quite unlikely that the $\$ 10$ per month price difference charged by MediaOne is related to a similar difference in marginal cost. Thus, the standard economic definition of price discrimination is satisfied.

134 Competitive Impact Statement, supra note 2, at 6.

135 Id. at 8.

136 Id. at 10. 
broadband content and services." ${ }^{137}$ Within the broadband access market, the DOJ considered the substitutability of four alternative broadband technologies. At the time of the merger, consumers in the United States could choose between cable modems, digital subscriber lines (DSL), direct broadcast satellites, and fixed wireless technologies to receive broadband Internet access. Like the FCC, the DOJ found that the broadband access market was dominated by cable companies and that only DSL might be a viable broadband alternative to cable modems within the next "several years." 138

Given the predominance of cable-based technologies in the broadband marketplace, AT\&T would acquire, as a result of the proposed merger, "substantial equity and management rights in both Excite@Home and Road Runner-two firms that, combined, serve a significant majority of the nation's residential broadband users." 139 Therefore, the DOJ concluded that the combination of Excite@Home and Road Runner "threatens to substantially lessen competition by increasing concentration in the market for aggregation, promotion, and distribution of residential broadband content."140 Excite@Home and Road Runner had already negotiated exclusive dealing arrangements with five of the seven largest cable television MSOs in the United States. ${ }^{141}$

To preserve competition in the market for the aggregation, promotion, and distribution of broadband content, the DOJ moved to ensure that Excite@Home and Road Runner would continue to operate independently of one another. The DOJ's proposed final judgment required AT\&T and MediaOne to divest their interests in Road Runner by December 31, 2000. Additionally, the DOJ limited the ability of AT\&T and MediaOne to negotiate any agreements with Time Warner and its subsidiaries for a period of two years following the divestiture, presumably under the rationale that a larger virtual footprint would increase the incentives of AT\&T to

137 Id. at 9.

138 Id. at 6-8. "As of early 2000 , approximately 70 percent of the subscribers to residential broadband service use a cable modem service in which data is transmitted over the facilities of a cable company. DSL services are the second most frequently used, but though the number of DSL users is growing rapidly, DSL still lags substantially behind cable modem service in market penetration and acceptance. Satellite and fixed wireless services have only a very small portion of residential broadband subscribers." Id. at 8 .

139 Id. at 5.

140 Id. at 2.

141 Id. at 8. "If the proposed merger were consummated, concentration in the market for aggregation, promotion, and distribution of residential broadband content and services would be substantially increased, and competition between Excite@Home and Road Runner in the provision of such services may be substantially lessened or even eliminated. Through its control of Excite@Home and substantial influence or control of Road Runner, AT\&T would have substantially increased leverage in dealing with broadband content providers, which it could use to extract more favorable terms for such services." Id. at 12. 
discriminate against unaffiliated content and conduit rivals. The DOJ believed that the divestiture requirements, along with limitations that the DOJ imposed upon subsequent agreements, would "ensure that Excite@Home and Road Runner (or any successor residential broadband service offered by Time Warner) will continue to be separate and independent of one another, thereby preventing the reduction or elimination of competition between them that otherwise would have resulted from AT\&T's acquisition of MediaOne."142

The FCC imposed no additional conditions on the merger of AT\&T and MediaOne. ${ }^{143}$ The FCC analyzed the post-merger conditions of the markets for both narrowband and broadband Internet services, yet the agency concluded that it need not distinguish between the narrowband and broadband markets to achieve its regulatory goals. With respect to competition in the broadband arena, the FCC concluded that the potential anticompetitive effects of the merger would be mitigated not only by competitive entry and technological innovation, but also by the terms of the applicants' proposed consent decree with the Department of Justice. Hence, the FCC declined to impose its own merger conditions to address competition in the market for broadband Internet access, services, and content. $^{144}$

Because MediaOne did not provide traditional dial-up Internet access services, the FCC reasoned, the merger would be "unlikely to have an adverse effect on competition and diversity in the provision of narrowband Internet access services."145 With respect to the merger's implications for broadband Internet markets, ${ }^{146}$ the FCC addressed three categories of anticompetitive concerns: broadband Internet content, broadband Internet applications and software, and "open/forced access." 147 The FCC considered the post-merger abilities and incentives of AT\&T-MediaOne to use its cable systems to exercise market power in broadband service markets. The FCC addressed concerns raised by commenters that the consolidation of the companies' assets in Road Runner and Excite@Home might threaten competition for broadband services, and the agency considered conditioning

142 Id. at 15.

143 Applications for Consent to the Transfer of Control of Licenses and Section 214 Authorizations from MediaOne Group, Inc., Transferor to AT\&T Corp., Transferee, Memorandum Opinion and Order, CS Docket No. 99-251, 15 F.C.C.R. 9816 (released June 6, 2000) [hereinafter Memorandum Opinion and Order].

$144 \mathrm{Id}$. ๆ 5.

145 Id. 7105.

146 For a thorough discussion of the FCC's definition of broadband Internet services, see BROADBAND TODAY, supra note 13.

147 Memorandum Opinion and Order, supra note 143, $17111-15$. 
its approval of the merger on the companies' willingness to accept an "open/forced access" agreement. ${ }^{148}$

The FCC found, however, that the explicit distinction between narrowband and broadband Internet access markets was irrelevant. ${ }^{149}$ The FCC acknowledged that the merger of AT\&T and MediaOne could pose anticompetitive threats to emerging markets for broadband Internet services, but "those harms will be avoided if: (a) consumers can choose among various alternative broadband access providers, such as DSL, wireless, and satellite; or (b) unaffiliated ISPs are permitted access to the merged firm's cable network." 150 The FCC was satisfied that a competitive market for broadband access already provided the former, and the agency was convinced that AT\&T had committed itself to providing the latter. ${ }^{151}$

In May and June of 1999, the Cable Services Bureau of the FCC convened a series of monitoring sessions "to study the state of the broadband industry and to identify any potential market failures." ${ }^{152}$ Despite the lead that cable companies enjoyed in broadband markets, and despite the likelihood that DSL would be the only viable alternative to cable in the nearto-middle term, the Cable Services Bureau concluded that each investment in a given broadband technology acts as a positive incentive to spur future investments in all other alternative broadband technologies. The Cable Services Bureau advised the FCC that regulatory intervention into broadband markets would likely retard growth in the industry and that, without governmental intrusion, "robust competition [between multiple alternative technologies] in the broadband industry in the long run is likely."

The Federal Trade Commission and the FCC began their review of the proposed merger of AOL and Time Warner in the summer of 2000. In a

148 The FCC received numerous comments and opinions regarding "open/forced access." See, e.g., Written Ex Parte Comments of Professors Mark A. Lemley and Lawrence Lessig, CS Docket No. 99251 (filed Nov. 10, 1999). The FCC also considered "open/forced access" comments regarding the program carriage rules for video programming. See 47 C.F.R. $\$$ 76.504(a) (2000) (channel occupancy limits); and 47 C.F.R. $\S 76.1301$ (c) (2000) (program carriage). But the FCC finds that because "Excite@Home and Road Runner are not services comprised only of video programming," AT\&T and MediaOne are permitted to deny unaffiliated ISPs access to their cable networks. Memorandum Opinion and Order, supra note $143, \Upsilon 86$.

149 "We find it unnecessary to determine in this proceeding whether a distinct broadband Internet access market exists, notwithstanding the rigorous debate on the record between the Applicants and commenters on this issue of market definition." Memorandum Opinion and Order, supra note 143, ๆ 116.

150 Id

151 "Given the nascency of broadband Intemet services, we find in this Order that growing competition from altemative broadband access providers, the Applicants' commitment to give unaffiliated ISPs direct access to the Applicants' cable systems, and the terms of Applicants' proposed consent decree with the Department of Justice requiring the divestiture of Road Runner make it unlikely that the merged firm would be able to dominate and threaten the openness and diversity of the Internet." Id. I 5 .

152 Id. at 31.

153 Id. at 33. See also Memorandum Opinion and Order, supra note 143, 11 117-19. 
letter to the merging firms, the FCC appeared to amend its position on open access. ${ }^{154}$ The Cable Services Bureau asked AOL and Time Warner for additional information "open access" to cable modem platforms. In particular, the bureau asked for all documents related to (1) the decision to renegotiate that exclusivity provision, (2) its stated decision to provide open access on Time Warner's cable modem platform after the merger is completed, and (3) additional details on the "AOL Anywhere" initiative, under which AOL has sought to negotiate deals to offer service over a number of technology platforms. ${ }^{155}$ If the market could be relied upon to provide a check against the merged firm's power, then no such investigation would be warranted. In a response to the FCC's request, AOL and Time Warner promised that they would not discriminate against ISPs and would let multiple ISPs use their cable lines. ${ }^{156}$

In an open letter to both regulatory agencies, EarthLink, an unaffiliated ISP seeking access to the Time Warner broadband network, revealed that Time Warner asked for "more than 50 percent of the revenue generated from EarthLink customers who use Time Warner cable lines." letter disclosed that Time Warner demanded a portion of the incremental revenue generated by EarthLink, including revenue from advertisers who pay to appear on the EarthLink site and from vendors who pay a transaction fee when customers buy merchandise or services from EarthLink. ${ }^{158}$ Finally, EarthLink said that Time Warner wanted to have a "presence" on EarthLink's home page, and that Time Warner wanted links to its sites from EarthLink's Web site. ${ }^{159}$ The letter raised serious concerns about whether the results of a voluntary negotiation between a cable provider with a large footprint and an access-seeking ISP are likely to lead to an efficient outcome.

In a less conciliatory fashion than used by the FCC, the FTC in late 2000 signaled its willingness to block the AOL-Time Warner merger outright unless the companies accept restrictions to curb their combined market power. ${ }^{160}$ In September 2000, the FTC suggested that the proposed merger of $\mathrm{AOL}$ and Time Warner merger could violate antitrust law because it "marries AOL's dominant position in Internet service with Time Warner's cable systems, which would dominate Internet access through cable lines in

\footnotetext{
154 Bureau Wants More Info on Open Access from AOL and Time Warner, TR DAILY, Aug. 15, 2000 , at $* 1$.

155 Id.

156 Reshma Kapadia, AOL-Time Warner Will Open Cable Systems, REUTERS, Sept. 7, 2000, at

$* 1$.

157 Alec Klein, Time Warner Access Pledge Questioned, WASH. POST, Sept. 30, 2000, at E1.

158 See id.

159 See id.

160 See Philip Shishkin and John Wilke, AOL-Time Warner Plan Hits Roadblock. WALL ST. J., Sept. 19, 2000, at A3.
} 
the cities they serve." 161 In particular, the FTC was concerned about access by Internet rivals to Time Warner's broadband cable lines. The companies were in talks with the FTC at the time of this writing.

\section{Conclusion}

Cable firms are well practiced in the art of vertical integration followed by discrimination. For example, the merger of Time Warner and Turner (primarily a content provider) in 1997 represented a major consolidation of the cable industry at the level of programming and cable infrastructure. In his review of the competitive impact of that merger, FTC Chairman Pitofsky concluded that "the launch of a new channel that could achieve marquee status would be almost impossible without distribution on either the Time Warner or Tele-Communications Inc. (TCI) cable systems."162 The Commission therefore found it necessary to limit TCl's ownership in Time Warner to a passive interest. ${ }^{163}$ The FTC recognized that, by expanding the size of Time Warner's cable footprint, the merged entity would have a greater incentive to discriminate against rival content providers.

Cable firms are similarly positioned to dominate the broadband industry. With control of both the broadband content and the pipes, a large footprint encourages the cable firm to discriminate against its unaffiliated content and conduit rivals. To remedy the risks of conduit and content discrimination, regulators should subject any pending mergers to an open access provision. In particular, the regulatory agencies should require vertically integrated cable firms to afford unaffiliated ISPs equal and nondiscriminatory access to the combined company's cable modem platform. Doing so will ensure that the incumbent cable provider does not evade or slow-roll the advent of open access, will promote investment in the broadband portal market by giving new entrants certain access to the merged company's cable customers, and will limit the cable firm's ability to engage in both conduit and content discrimination.

Specifically, imposing an open access condition on a cable firm will undermine its ability to engage in conduit discrimination by ensuring the preservation of a robust broadband portal marketplace. Thus, even if the combined company elects to distribute its service only through cable

161 Martin Peers and Julia Angwin, Time Warner, AOL Say Access Won't Derail Deal, Wall ST. J., Sept. 6, 2000, at A3.

162 Statement of Chairman Pitofsky and Commissioners Steiger and Varney, In re Time Warner Inc., at 3, Docket No. C-3709 (filed Feb. 3, 1997). He was correct as demonstrated the same year when Fox attempted to launch a new cable news channel that competes with CNN the Time Warner-Turner (TWT) news channel. TWT refused Fox carriage in the city of New York, which led to protracted litigation. In a settlement, TWT subsequently did provide carriage to the Fox news channel.

163 See id. 
modems, competing unintegrated portals can still take advantage of cable's dominant position in the broadband transport market, leaving competing conduit providers with enough content to justify continued investment. Likewise, imposing an open-access condition on a cable firm will undermine its ability to engage in content discrimination. Even if the merged company elects to block all outside content, unaffiliated portals and content providers can still reach cable customers through a competing ISP. Customers seeking access to content generated outside the cable firm will thus not have to switch to DSL or some other transport conduit that suffers from a lower rate of market penetration. 


\section{APPENDIX: ALTERNATIVE SPECIFICATIONS OF REGRESSION OF BROADBAND ACCESS PRICES ON NARROWBAND ACCESS PRICES}

\section{Specification 2}

Left hand side variable: Log of Excite @Home access price plus amortized monthly cost of installation

\begin{tabular}{lccc}
\hline Variable & $\begin{array}{c}\text { Est. } \\
\text { Coefficient }\end{array}$ & $\begin{array}{c}\text { Est. Std. } \\
\text { Error }\end{array}$ & $\begin{array}{c}\text { Est. t- } \\
\text { statistic }\end{array}$ \\
\hline Intercept & 3.98 & .107 & 37.2 \\
Log Price of Narrowband & 0.012 & .031 & 0.382 \\
Access* & & & \\
\hline Number of observations & 43 & & \\
Standard error of regression & .002 & & \\
$\mathrm{R}^{2}$ & .004 & & \\
\hline
\end{tabular}

* Note: Narrowband access price is the log of the price of a second telephone line plus second-line fees plus amortization of the installation cost.

\section{Specification 3}

Left hand side variable: Log of cable broadband access price plus amortized monthly cost of installation

\begin{tabular}{lccc}
\hline Variable & $\begin{array}{c}\text { Est. } \\
\text { Coefficient }\end{array}$ & $\begin{array}{c}\text { Est. Std. } \\
\text { Error }\end{array}$ & $\begin{array}{c}\text { Est. t- } \\
\text { statistic }\end{array}$ \\
\hline Intercept & 4.86 & 0.564 & 8.62 \\
Log Price of Narrowband & -0.029 & 0.033 & -0.877 \\
Access* & & & \\
Log Population Density & 0.001 & 0.010 & 0.057 \\
Log Median Household Income & -0.028 & 0.064 & -0.433 \\
\% Population Age 65 and Older & -0.006 & 0.006 & -1.16 \\
\% Population Age 35 to 54 & -0.009 & 0.009 & -0.979 \\
\% Population Under Age 5 & -0.016 & 0.022 & -0.757 \\
Road Runner Indicator & -0.114 & 0.014 & -8.07 \\
\hline Number of observations & 59 & & \\
Standard error of regression & 0.002 & & \\
$\mathrm{R}^{2}$ & 0.600 & & \\
\hline
\end{tabular}


Residential Demand for Broadband

\section{Specification 4}

Left hand side variable: Log of Excite@Home access price plus amortized monthly cost of installation

\begin{tabular}{lccc}
\hline Variable & $\begin{array}{c}\text { Est. } \\
\text { Coefficient }\end{array}$ & $\begin{array}{c}\text { Est. Std. } \\
\text { Error }\end{array}$ & $\begin{array}{c}\text { Est. t- } \\
\text { statistic }\end{array}$ \\
\hline Intercept & 4.81 & 0.653 & 7.36 \\
Log Price of Narrowband & -0.0003 & 0.041 & -0.007 \\
Access* & & & \\
Log Population Density & 0.006 & 0.012 & 0.506 \\
Log Median Household Income & -0.077 & 0.083 & -0.929 \\
\% Population Age 65 and Older & -0.001 & 0.007 & -0.157 \\
\% Population Age 35 to 54 & -0.001 & 0.011 & -0.112 \\
\% Population Under Age 5 & 0.002 & 0.028 & 0.110 \\
\hline Number of observations & 43 & & \\
Standard error of regression & 0.002 & & \\
$\mathrm{R}^{2}$ & 0.056 & & \\
\hline
\end{tabular}

